\title{
Da experiência de escrever ao ato da escrita: vida e arte na poética de Cacaso
}

\author{
Dissertação apresentada ao programa de pós- \\ graduação em Teoria Literária e Literatura \\ Comparada do Departamento de Teoria \\ Literária e Literatura Comparada da \\ Faculdade de Filosofia, Letras e Ciências \\ Humanas da Universidade de São Paulo para a \\ obtenção do título de Mestre em Letras.
}

Orientador: Prof. Dr. Roberto Zular. 


\section{Autorizo a reprodução e divulgação total ou parcial deste trabalho, por qualquer meio convencional ou eletrônico, para fins de estudo e pesquisa, desde que citada a fonte.}

PROVASE, Lucius

Da experiência de escrever ao ato da escrita: vida e arte na poética de Cacaso / Lucius Provase; Orientador Roberto Zular. - São Paulo, 2010.

$86 \mathrm{f}$.

Dissertação (Mestrado - Programa de Pós-Graduação em Teoria Literária e Literatura Comparada) - Faculdade de Filosofia, Letras e Ciências Humanas da Universidade de São Paulo.

1. Poética. 2. Literatura Brasileira. 3. Poesia Marginal. 4. Antônio Carlos de Brito. I.Título II. Zular, Roberto 
a Juliana 


\section{Agradecimentos}

Aos meus pais, Elisabeth e Edelcio, pelo prazer da leitura, por apoiar-me mesmo sem saber exatamente o que eu faço.

A minha irmã, Paloma, pelo apoio mesmo a distância.

À Professora Maria Augusta Fonseca, pela iniciação que não teve início, mas começou tudo isso.

À Professora Claudia Pino, pelos livros que mudaram a minha vida.

Aos colegas do Grupo Criação e Crítica, pelas discussões que pareciam não levar a lugar algum. Um agradecimento especial à Monica e à Samira, pelo tanto que aprendi, pelas provocações, brigas e discussões.

À professora Viviana Bosi, pela leitura atenta, pelas indicações de leitura, pela busca de uma maior entendimento dessa mesma poesia que tanto me encantou

Ao professor Marcos Moraes, pelos caminhos indicados, pelas sugestões de aproximações e por se revelar um grande leitor de Cacaso.

À Coordenação de Aperfeioçoamento de Pessoal de Nível Superior, pela bolsa que em muito auxiliou esta pesquisa.

Aos colegas do grupo de estudos Zé, Fernanda, Fernando, Fábio, Eduardo e Ricardo. O convívio foi pouco, mas bastante proveitoso.

Aos funcionários do Departamento de Teoria Literária e Literatura Comparada Maria Ângela Aiello Bressan Schmidt, Suely Maria Regazzo, Zilda Ferraz e, em especial, Luiz de Matto Alves pela atenção, pelo cuidado e por realizar tarefas que eu deveria ter feito.

Ao professor Roberto Zular, pela paciência, por me mostrar caminhos de leitura e escrita que eu desconhecia.

À Juliana, pelo cuidado do dia-a-dia em meio a tantas descobertas, por não deixar que o cotidiano se tornasse um peso. 


\section{Indefinição}

pois assim é a poesia:

esta chama tão distante

mas tão perto de

estar fria.

Cacaso

Marginal é quem escreve à margem, deixando branca a página

para que a paisagem passe

e deixe tudo claro à sua passagem

Marginal, escrever na entrelinha, sem nunca saber direito

quem veio primeiro,

o ovo ou a galinha.

Paulo Leminski 


\section{RESUMO}

PROVASE, L. Da experiência de escrever ao ato da escrita: vida e arte na poética de Cacaso. 2010. 83 f. Dissertação (Mestrado) - Faculdade de Filosofia, Letras e Ciências Humanas, Universidade de São Paulo, 2010.

Esta dissertação pretende apresentar uma leitura da poética de Cacaso, partindo de uma comparação entre o modernismo, frequentemente visto como forte influência para a poesia dos anos 70, e os textos do poeta mineiro e chegando ao livro Beijo na boca de 1975, o qual consideramos ser a obra mais madura de Antônio Carlos de Brito. Divido em três partes, o trabalho pretende se concentrar no uso que Cacaso faz de diversas situações enunciativas, ressignificando os enunciados. Na primeira parte, a questão da liberdade é trabalhada, a qual é buscada nos poetas modernistas, principalmente Mário de Andrade e Oswald de Andrade; na segunda parte o foco é nas diferenças de abordagem, quanto ao tema da liberdade e do uso de técnicas poéticas consagradas pelos modernistas, causadas pelas diferentes questões tratadas no campo literário; a terceira e última parte foca-se na especifidade do texto cacasiano, não apenas em relação aos modernistas, mas em relação aos outros poetas dos anos 70 .

Palavras-Chave: Antônio Carlos de Brito, Poética, Poesia Marginal, Literatura Brasileira. 


\begin{abstract}
PROVASE, L. From experience to act: life and art in Cacaso's poetics. 2008. 83.p Dissertation (Master's Degree) - Faculdade de Filosofia, Letras e Ciências Humanas, Universidade de São Paulo, São Paulo, 2010.

This dissertations intends to present a view of Cacaso's poetics, beginning at a comparison between the brazilian modernism from 20's, usually seen as a very strong influence for the poetry of the 70's, and Cacaso's texts. Divided in three parts, this work focus in finding how Cacaso deals with a variety of enunciations, resignifying the enunciates, arriving at the 1975 book, Beijo na boca. In the first part, the liberty, which comes from the modernista poets, mostly Mário de Andrade and Oswald de Andrade, is the starting point; in the second part, the focus is on why there are differences on the approach and use of liberty and other poetic tecniques between the modernists and the poets of the 70's, comparing only the literary fields; the third and last part centers on the especifities of Cacaso's poetics not only concerning the relation with the modernists, but also the relation with other poets from the 70 's.
\end{abstract}

Keywords: Antônio Carlos de Brito, Poetics, Marginal Poetry, Brazilian Literature. 


\section{Indíce}

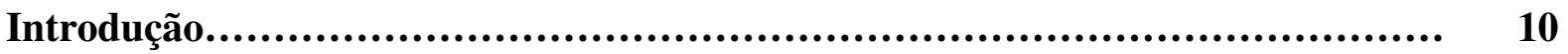

\section{As semelhanças: o caminho para a liberdade}

1. O marginal, os modernistas e a escrita rarefeita........................... 12

2. Um leitor dos modernistas: em busca da liberdade......................... 14

3. A relação entre arte e vida no modernismo.................................. 18

3.1 Mário................................................................ 18

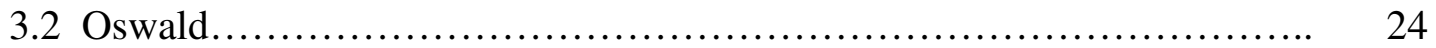

4. Arte e vida em Cacaso................................................ 24

\section{As diferenças: em busca de um campo (literário) perdido}

1. O que está por vir?.......................................................................... 34

2. O que são campos literários?............................................................. 35

3. O campo literário modernista.......................................... 37

3.1 A busca da autonomia............................................. 38

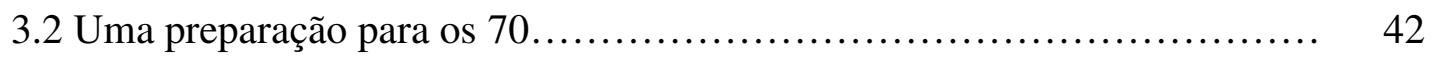

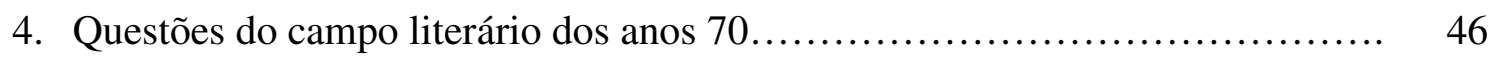

4.1 Um breve panorama do período................................... 46

4.2 Os poetas e suas vidas........................................ 49

$4.3 \mathrm{O}$ espaço discursivo da literatura................................. 50

5. A interrupção de um movimento...................................... 58 


\section{A especificidade: a escrita em suspensão}

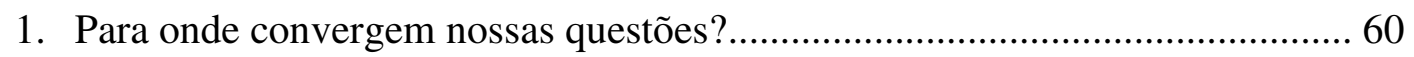

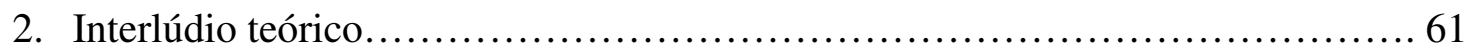

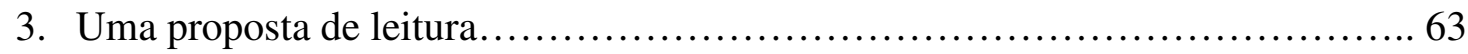

$3.1 \mathrm{Nem}$ dono nem inquilino.................................... 64

3.2 A subjetividade é um problema coletivo........................... 70

3.3 Quando a expressão é construída, quando a construção é expressa........... 74

Bibliografia...................................................................... 83 


\section{Introdução}

\section{Um breve histórico da pesquisa}

Este texto é marcado pelo acaso. Logo em meu primeiro ano de faculdade decidi que seguiria a vida acadêmica. Procurei pela professora Maria Augusta Fonseca, querendo uma orientação em uma pesquisa ainda em formação sobre um dos três poetas a seguir: Paulo Leminski, Ana Cristina César ou Cacaso. Ela disse que só poderia me orientar se o objeto de estudo fosse Cacaso, mas poderia indicar outros professores se não fosse o Cacaso. Optei por continuar com a professora Maria Augusta, Cacaso foi a consequência.

Pelas razões mais diversas a iniciação científica nunca se iniciou de fato. Continuei a minha pesquisa sobre o processo de construção de Cacaso, mas com a única pesquisadora de crítica genética que conhecia, a professora Claudia Pino. Com ela continuei minha orientação até o final da graduação. Chegamos a um impasse quando passaria para o mestrado: Claudia é professora da área de francês e eu faria minha pesquisa em literatura brasileira. Então surgiu a figura do professor Roberto Zular, ele também estudioso da poesia marginal, tinha a crítica genética como uma abordagem teórica. Descobri, com o passar do tempo, que havia mais interesses em comum em nossas pesquisas: a tensa relação entre fala e escrita na literatura brasileira, a busca por uma base teórica que desse conta do problemas que indentificávamos. Chegamos ao linguista e teórico da literatura Henri Meschonnic. É ele quem permeia minhas reflexões ainda que muitas vezes não seja citado.

Os problemas que aparecem nessa dissertação também são marcados pelo acaso. Indentifiquei uma tensão em Cacaso, algo que me parecia diferente dos outros poetas, mas que era impossível enunciar. Tateava as questões que enxergava em seus poemas, algumas vezes tangenciando-as, outras formulando-as de maneira superficial, aprimorando a leitura a cada análise. Espero ter, nesta dissertação, formulado minhas questões com clareza e oferecido tantas perguntas quantas eu tive em meu primeiro contato com a poesia de Cacaso.

\section{Os problemas da dissertação}

A primeira questão que se colocou para mim, ao começar o processo de escrita foi a forma que seria utilizada para tratar dos textos de Cacaso. A dissertação tradicional entraria em forte contraste com o tema que eu iria tratar, por outro lado, a forma ensaio não seria 
viável na academia. Optei por um caminho do meio: os capítulos funcionam muito bem em conjunto, mas possuem uma certa autonomia. Esse caminho do meio também aparece na escolha do primeira pessoal do plural, diferente da primeira do singular usada nesta introdução. É certo que essa postura traz ônus (espero que alguns bônus): abri mão de explicar e tratar a vida de Cacaso, começando diretamente nas questões que considero mais importantes; abri mão também de dividir o texto em capítulos, embora eles funcionem como tal.

No primeiro capítulo, pelo viés da liberdade, trato da questão da arte e vida em Cacaso, sugerindo que essa relação é extraida por ele de uma leitura atenta dos modernistas. No segundo, trato das diferenças do campo literário modernista e do campo literários dos anos 70. No terceiro e último capítulo, a partir das leituras realizadas nos capítulos anteriores, pretendo apresentar uma chave de leitura para a poesia cacasiana, tratando de sua especificidade.

A minha intenção, se é que de fato ela importa na leitura, era que os capítulos fossem em um crescendo: o primeiro trataria das semelhanças entre os modernistas e os marginais, principalmente Cacaso; o segundo trataria das diferenças entre essas duas gerações; o terceiro trataria da especificidade da poesia de Cacaso. Essa questão é alardeada já nos títulos. Procurei tratar minha relação com a poética de Cacaso, não como uma relação sujeito-objeto, mas um diálogo entre funções-sujeito.

Em uma releitura, penso que consegui alcançar esse objetivo, mas o crescendo não foi regular, há algumas idas e vindas, há certas passagens em que passo da poesia de Cacaso para a poesia marginal como um todo, há outras em que uso de exemplo apenas um poeta para falar de toda poesia modernista. Tudo isso era intencional, transitar entre o geral e o específico. É certo que isso apresenta dificuldades, talvez inerentes ao próprio estudo da literatura, no trânsito entre o universal e o particular, o geral e o específico. Espero que as dificuldades inerentes ao processo, que a minha dificuldade com a escrita, talvez o verdadeiro problema que me fez procurar a questão da escrita em Cacaso, não tenham se tornado dificuldades para a leitura do texto. 


\section{As semelhanças: o caminho para a liberdade}

\section{O marginal, os modernistas e a escrita rarefeita}

Há um poema de Cacaso que representa bem a visão geral que se tem sobre a poesia marginal. O poema chama-se "Na corda bamba", do livro, de 1978, de mesmo nome:

NA CORDA BAMBA

p/ Chico Alvim

POESIA

EU NAO TE ESCREVO

EU TE

VIVO

E VIVA NŌS :

A começar pelo título, analisado por Heloísa Buarque mais a frente, passando pela dedicatória, pela relação arte e vida, o poema brinca com as diversas situações enunciativas presentes no texto. Passamos do mundo da experiência, para o mundo da construção, atravessamos as relações pessoais do poeta por meio da dedicatória, saímos da escrita para a fala sem nunca repousar em uma dessas diversas instâncias. A poesia, não o poema, é vivida, e não escrita. No entanto, lá está o poema, não a poesia, escrito, contrariando o que se anuncia. Criada a tensão, espera-se uma solução deixada para a última estrofe com apenas um verso. Encontramos, contudo, uma saída pela tangente: a resolução para essa questão não está no poema, ao menos não em nenhuma das situações enunciativas criadas por ele. O último verso joga o poema para uma outra enunciação. 
O texto seria representativo da leitura crítica corrente sobre a poesia dos anos 70 , que a associa às práticas de escrita voltadas antes à expressão do que à reflexão, textos que buscavam apenas cristalizar o momento, uma espécie de "versão hedonista do processo discriminatório da modernização brasileira" para retomar as fortes palavras do conhecido ensaio "Poesia ruim, sociedade pior", de Iumna Simon e Vinicius Dantas; um uso ultrapassado, histórica e tecnicamente, de procedimentos modernistas, principalmente a coloquialidade, que não mereceria uma aproximação mais cuidadosa. Ainda segundo os críticos, em uma leitura que poderia ser dirigida ao poema acima:

nos poemas dessacralizados compõe-se um painel caótico e banal do cotidiano que é a imagem da dessacralização geral de um mundo igualmente caótico e absurdo. Só que fica difícil discernir no valetudo dessa sensibilidade se os poemas são menos banais que o mundo que os inspirou.(Simon e Dantas, 1985, p 57)

Se é para retratar uma realidade banal de forma banal, qual o sentido do poema? A experiência não seria sempre superior ao seu retrato? A força da leitura desses críticos é "enfiar o dedo na ferida", é cutucar o ponto frágil da produção poética dos anos 70 , ao questionar a validade da escrita se igualada à própria experiência.

A mesma questão reaparece em Heloísa Buarque, que propõe uma leitura em outra chave do poema rápido e rasteiro:

que a aparente gratuidade proposta no poema coloca em pauta a contradição
que inevitavelmente se esboça quando nos aproximamos de um poema
"autenticamente marginal". Ou seja, quando o poeta marginal propõe uma
quase coincidência entre poesia e vida, essa proposta poderia, no limite,
resultar no desaparecimento da própria poesia. É a produção poética
literalmente "na corda bamba" (que aliás dá nome não apenas ao poema,
mas também ao livro), na qual o poeta marginal consegue equilibrar-se
quase sempre com alguma dificuldade. Um caminho difícil e conflituado
que pode ser entrevisto na própria trajetória da obra poética de
Cacaso.(Hollanda, 2003)

Uma negação da própria poesia, ou sua impossibilidade diante do impasse que se coloca entre experiência e construção, entre vida e arte, essa é a leitura proposta para o poema. O clímax dessa relação tensa entre esses elementos seria o enfraquecimento da palavra escrita. A leitura da poética de Cacaso que proporemos é construída na tensão entre essas duas percepções, mesmo porque em ambas há a visão de que a escrita é colocada em crise não apenas nesse poema especificamente, mas nos textos marginais como um todo. 
No que concerne ao Cacaso, ao menos em seus textos mais maduros, há um impasse entre fala e escrita, experiência e literatura, expressão e construção. Todos binômios que representam a mesma relação, maneiras diferentes de se aproximar de uma mesma questão, a saber, a relação entre arte e vida. Um questão que reaparece com frequência na literatura brasileira, sendo trabalhada também pela crítica das maneiras mais distintas.

Para nós, tendo os textos de Cacaso como foco, é preciso compreender como isso se dá em seus escritos, separando-os, portanto, do restante da produção marginal. O segundo ponto é buscar compreender a trajetória que levou a essa rarefação da escrita; em nosso entendimento, a compreensão passa pelos primeiros modernistas, pois a presença deste se dá não apenas no poeta Cacaso, através da referência a determinados procedimentos poéticos, mas no crítico Cacaso, através da leitura atenta de escritores como Mário, Bandeira e Oswald. Combinando essas duas aproximações, acreditamos ser possível melhor compreender as reflexões sobre a escrita que aparecem nos textos do escritor mineiro.

\section{Um leitor dos modernistas: em busca da liberdade}

Antônio Carlos de Brito era não apenas um escritor, mas professor universitário e pesquisador ativo, participando de diversos grupos de estudo com outros escritores, alunos, amigos. Fazia do exercício teórico parte do seu trabalho criativo; Charles, em entrevista concedida a Heloísa, afirma que ele era quem dava seriedade à produção daquela geração, justamente através da teorização do movimento. O papel de teórico da geração dado a ele é aceito de forma unânime por outros poetas. Para exemplificar ${ }^{1}$, um trecho da entrevista para o site Portal Literal:

Hbh: Acho que Cacaso marcava uma posição claramente diferenciada também porque era antes de mais nada um aglutinador. Ele conseguia transitar quase naturalmente entre os muitos grupos daquele tempo, articulando projetos, coleções e até "explicando" para os poetas o que eles estavam fazendo.

Cpc: Isso era muito engraçado. Cacaso era o nosso teórico. A gente ficava pasmo com o que ele dizia sobre a gente. Cacaso tinha o personagem do professor. Guilherme Mandaro foi o nosso primeiro professor, mas se suicidou cedo, logo no começo. Cacaso instigava a

\footnotetext{
${ }^{1}$ Além de Charles, há ainda o depoimento de Carlito Azevedo na revista Inimigo Rumor número 8, o reconhecimento do papel exercido por Cacaso pelo crítico Carlos Messeder no livro Retrato de Época, entre outros depoimentos, incluído aí a famosa frase de Paulo Leminski, pronunciada após um encontro de poetas: "nenhum lance de dados abolirá o Cacaso".
} 
produção. Ele interpretava o que a gente escrevia, dava seriedade na coisa e isso fazia a gente não abandonar o barco.

O que Charles chama de "dar seriedade para a coisa" é a busca de Cacaso por um lugar no campo literário para a poesia marginal. Esse processo passa pelo modernismo. E é nos ensaios, na produção teórica, que se encontram as referências mais claras e explícitas sobre a produção modernista; é nos ensaios que podemos perceber de que modo o poeta e crítico mineiro recebia a produção daqueles escritores de 22, principalmente a ensaística de Mário de Andrade. São nos ensaios que percebemos que a leitura que Cacaso faz da escrita modernista é uma forma de validar sua própria obra e dar a ela algum tipo de lastro, uma filiação que não se limite apenas à cópia de coloquialismos, ironias e outros procedimentos. Cacaso busca nos modernistas a justificativa para a sua busca pela liberdade da escrita.

A liberdade para a escrita também aparece na relação que Cacaso estabelece com a canção. Apontada como consequência de sua natural musicalidade (relatos sobre sua fácil relação com a música são inúmeros) a canção na obra de Cacaso é muitas vezes vista como um aparte, mais um papel dentre os diversos que ele ocupa. Em nossa leitura, assim como no papel do teórico que se volta ao modernismo, o letrista é uma tentativa de ocupar espaços, pensando sempre nas possibilidades, pensando em se soltar das diversas amarras que vivenciava.

O sentido que Antônio Carlos de Brito dava à palavra liberdade pode ser inferido a partir de um ensaio bastante interessante, sobre Mário de Andrade. O texto é uma espécie de resenha crítica/ensaio, de 1978, sobre o livro O Banquete de Mário. Nesse livro, o modernista discute algumas questões estéticas, muitas ligadas à música, mas cujas reflexões servem também à literatura. Uma em particular serve de mote para todo o ensaio: a relação entre o modernismo e o que eles, os modernistas, chamavam de academismo. Surge uma interpretação interessante de Cacaso sobre a crítica que Mário faz aos academistas:

\footnotetext{
"Segue-se, nas palavras do virtuose, que 'a maior conquista do modernismo brasileiro foi sistematizar no Brasil, como princípio mesmo da arte, o direito de errar. Vê-se, por aí, que o problema do academismo não é propriamente acertar, mas acertar sempre, e para tal é levado a abolir não o erro, mas a sua simples possibilidade, e daí só pisar em terreno bem firme e já provado. E daí a rotina inevitável.” (Brito, 1997, p. 159)
}

O escritor mineiro procura compreender o que seria a situação da literatura contemporânea, partindo da leitura de Mário. Os acadêmicos de Cacaso seriam a geração de 45 e, principalmente, os concretos: 
"O concretismo vai abolir o direito de errar, expressão da insuficiência da linguagem, mas que leva à inovação e ao experimento, pela supressão pura e simples do contexto onde tudo isso ocorria: a palavra versificada, mas sobretudo a livre expressão, o verso livre. Surge uma concepção de experimento curiosa, onde o risco da criação dá lugar à fixidez da regra, a insuficiência à plenitude, o questionamento à quase idolatria." (Brito, 1997, p.164)

A oposição ferrenha de Cacaso à geração anterior explica-se, pois o poeta mineiro enxergava nesses escritores uma quebra das grandes conquistas do modernismo. Mas o que seria "experimentar" no entendimento do escritor dos anos 70? Segundo sua leitura do romantismo e do modernismo, havia, nesses movimentos, "a dissolução de regras, a quebra de hierarquias, planos embaralhados, valores subvertidos, tudo aquilo que configura a modificação e o questionamento profundo da fisionomia estabelecida do discurso". Mais do que isso. Abrir mão do direito de errar é abrir mão da arte.

"O direito de errar, que tem como consequência direta a pesquisa e a inovação, não é desculpabilidade ou justificativa para o erro, enquanto imperícia contingente deste ou daquele artista, mas é a recuperação da sua possibilidade como parte e condição mesma do fazer artístico." (Brito, 1997, p.159)

Aproximar-se do modernismo de 22 mostra dois movimentos: validar a leitura que é feita por Antonio Carlos de Brito do momento histórico no qual ele vive; afastar-se de outros movimentos literários, como o concretismo, invalidando-os. Podemos inferir, embora isso não seja dito de forma explícita em nenhum momento, nem mesmo em outros textos, que Cacaso roga a si mesmo e, provavelmente, a alguns de seus contemporâneos, o papel de continuadores do modernismo. Há que se entender que continuadores no sentido de fazerem da experimentação o motivo mesmo da construção artística. Dito de outro modo, não existe a intenção de continuar o projeto modernista, muito pelo contrário. Em outros escritos críticos podemos perceber que não há mais espaço para a construção de projetos, o que se faz necessária é a elaboração de um espaço discursivo que questione "a fisionomia estabelecida do discurso".

Parece que a ponte que deve ser feita entre o modernismo de 22 e Antonio Carlos de Brito não deve buscar as óbvias semelhanças entre esses dois momentos poéticos, mas as diferenças, não apenas históricas, mas no aproveitamento da matéria poética, da matéria escrita ela mesma. O "confronto direto" entre o poeta dos anos 70 e o modernismo pode ajudar a revelar ainda mais do que fica apenas esboçado nesses textos críticos: a necessidade de liberdade coincide com a necessidade de se criar um espaço discursivo livre. Nada poderia 
ser mais óbvio do que reforçar o caráter livre, ligado ao experimentalismo, da arte, em um momento de grande repressão.

Provavelmente, haverá um questionamento acerca do que escrevemos até aqui: em que momento a presença dos modernistas pode ser vista num texto como o que analisamos? Que lição exatamente foi apreendida dos modernistas? O que procuramos mostrar, ainda que brevemente, é que o poeta mineiro tomará como lição máxima dos modernistas a busca pela liberdade, o experimentalismo.

Essa busca também pode ser visualizada na canção. Um exemplo interessante, combinando o teórico e o letritsa, é a leitura que faz de Bandeira, em texto de 1986, publicado em encarte de um disco. Vê nele o poeta que, entre nós, "mais sacou as sutis implicações da parceria musical" e retoma uma citação do poeta pernambucano, na qual Manuel Bandeira mostra que a musicalidade do poema é subentendida. Tal musicalidade, ainda segundo o crítico mineiro, "é nossa linguagem nascente, ligada à pesquisa e criação de nossa identidade." Daí ele deriva que é "preciso ser livre para se pesquisar. E a pesquisa é a pesquisa da liberdade" (Brito, 1997, p. 195). Ou seja, a musicalidade em Bandeira viria tanto da percepção do poeta quanto as sutilezas da língua, quanto de uma percepção de que, mais uma vez nas palavras de Cacaso, "o constrangimento natural da parceria é, no fundo, uma associação de liberdade”. Interessante notar não apenas a preocupação com a música na poesia, algo que mesmo não sendo perceptível nos poemas de Cacaso, é frequentemente relatado como uma característica marcante do escritor ${ }^{2}$, mas a maneira como ele percebe a liberdade para a escrita: algo que pode tomar a forma de um constrangimento, uma tensão.

A visão do próprio Cacaso sobre a relação música e poesia aparece em texto anterior, de 1982, no qual tenta explicar uma declaração feita a revista Veja sobre a relação entre letras de música e poemas. Problematiza a questão explicitando as diferenças, apoiando-se também em Bandeira e na citação famosa do pernambucano: "É que por maiores que sejam as afinidades entre duas artes, sempre as separa uma espécie de abismo". Encara a dificuldade dessa relação, sem apelar para simplificações ou hierarquizações. Rememora Vinicius, colocando em grande conta. Aponta ainda as diferenças de mercado entre uma arte e outra: "o poeta de livro não faz carreira através do mercado; na área da letra não se faz carreira senão no mercado". O que interessa, contudo, é o encerramento do texto: "Uma letra, quando lida, vira poema? Um poema musicado vira letra? O poeta é poeta, quando faz letra? O mercado é

\footnotetext{
${ }^{2}$ Ler depoimento de Pedro Alvim na Inimigo Rumor n8
} 
uma liberdade a mais ou a menos?" (Brito, 1997, p. 227). A última pergunta parece deslocada, posto que a questão da liberdade não aparece em outro momento do texto.

A questão que Cacaso coloca talvez seja para ele mesmo, seja um autoquestionamento, uma dúvida que ele carrega, pois, em um retrato belíssimo traçado por Roberto Schwarz, pode-se ler:

A certa altura, Cacaso imaginou que a sua vida de intelectual e artista seria mais livre compondo letras de música popular do que dando aulas na faculdade. Na época chegou a idealizar bastante a liberdade de espírito proporcionada pelo mecanismo de mercado.(Schwarz, 2007, p. 18)

Podemos afirmar que a liberdade criativa era essencial para o escritor mineiro. Por isso ela aparece ali, um tanto despropositada, meio sem pé nem cabeça. Cacaso usa Bandeira em sua reflexão sobre a canção para justificar a sua própria busca pela liberdade. Ambos aparecem como justificativa. O próprio percurso do poeta mineiro em direção à canção, como bem mostra o depoimento de Roberto Schwarz, era em busca da liberdade. Esse mesmo anseio se mostrará na maneira com que Cacaso se aproxima dos modernistas em seus textos críticos.

Na busca pela liberdade é que aparecerá a instabilidade, que mencionamos na leitura do poema "Na corda bamba", entre escrita e fala, expressão e construção. Talvez seja essa instabilidade, aliada a busca pela liberdade, que o tenha levado a optar, ao final de sua vida, pela canção ${ }^{3}$, uma forma que leva ao limite essa relação. De qualquer modo, o próximo passo é buscar a outra ponta nesse diálogo entre Cacaso e os modernistas, menos explícita, mas certamente não menos importante: a relação arte e vida.

\section{A relação entre arte e vida no modernismo}

\subsection{Mário}

Cacaso era leitor atento dos modernistas. Mário era grande referência para ele, sobretudo na oposição explícita que fazia aos concretos e à geração de 45. Usou não apenas uma atitude diante da literatura, mas a percepção do fenõmeno literário mesmo. Daí decorre a postura diante da arte e da vida.

Impossível afirmar que foi Antônio Carlos de Brito quem propos a leitura da relação entre arte e vida para a poesia marginal. Até porque, dois anos antes da publicação de seu

\footnotetext{
${ }^{3}$ Cacaso exerceu durante muito tempo o papel de letrista e não apenas ao fim de sua vida. Queremos dizer que ao final da vida, ele buscava viver apenas como letrista.
} 
primeiro livro de poesia marginal, o Grupo Escolar, já haviam sido publicados outros livros com uma temática marginal, os quais despertaram a atenção da crítica para uma curiosa revitalização da poesia. Faremos, contudo, a suposição de que Cacaso vai aproveitar essa relação para imprimir um viés teórico que lhe era caro: vai teorizar a poesia marginal a partir de uma perspectiva modernista.

Mais uma vez Mário será a referência principal, mas não única, no quesito arte e vida. É notório o interesse do poeta paulistano pelas relações entre lírica e técnica; são muitos os textos nos quais ele se debruça sobre o que chama de psicologia do escritor. Dito de outro modo, não é preciso buscar com lupas para encontrar diversas referências sobre a relação entre arte e vida, entre o que Mário chama de expressividade, lírica, psicologia e entre o que chamava de construção, técnica. Se tomarmos o famoso "Prefácio Interessantíssimo" e seu correlato "A escrava que não é Isaura", encontraremos a fórmula: Lirismo + Arte = Poesia, sendo que arte é entendida como trabalho, o esteticismo e lirismo, por outro lado, vêm da necessidade de expressão. A fórmula aparece em ambos textos e parece refletir a preocupação de Mário em dar credibilidade ao então incipiente modernismo. A preocupação, contudo, da relação entre a expressão e construção, uma das muitas faces da relação arte e vida, é constante.

Em ensaios posteriores Mário mostra reflexões com o mesmo teor, mas mais atentas aos exageros e a possíveis falhas. Um exemplo, retirado do "Elegia de Abril":

Nós éramos abstecionistas, na infinita maioria. Nem poderei dizer 'abstencionistas', o que implica uma atitude consciente do espírito: nós éramos uns inconscientes. Nem mesmo o nacionalismo que praticávamos com um pouco maior largueza que os regionalistas nossos antecessores, conseguira definir em nós qualquer conciência da condição do intelectual, seus deveres para com a arte e a humanidade, suas relações com a sociedade e o estado. (Andrade, 1974 p. 186)

O interessante livro de Lafetá, 1930: a crítica e o modernismo, analisa muito bem essa postura de Mário, ao discordar de algumas leituras que Roberto Schwarz realiza no ensaio "O psicologismo de Mário de Andrade". Retomaremos a citação do texto de Schwarz, na qual ele comenta alguns pontos básicos de A escrava que não é Isaura, para a seguir incluir a "resposta" de Lafetá.

Voltando: a descoberta do menino Rimbaud tem consequências imediatas: a poesia deve ser a pura grafia do lirismo, despido de qualquer impedimento de ordem material ou intelectual; versos e rimas devem ser livres, a lógica não tem que ditar normas. O tema, que é uma delimitação 
lógica dentro do campo mais vasto do assunto, deve desaparecer. Os movimentos da subconsciência devem ser inteiramente respeitados. Mesmo as resistências do medium expressivo, a linguagem estruturada, devem ser rompidas - inventem-se neologismos e sintaxes. A linguagem é pura serviçal do subconsciente e deveria, para coerência absoluta, anular-se de uma vez.(Schwarz, 1968, p.4)

Antes das objeções de Lafetá, cabe ressaltar as semelhanças entre as ressalvas que Schwarz faz à postura teórica de Mário, e as observações que Simon e Dantas fazem sobre os poemas marginais. No limite, essa prevalência da lírica sobre a técnica, da experiência sobre a construção, só pode levar a uma linguagem nula, posto que subserviente ao subcosnciente, ao imediatismo: "Essas seriam sem dúvida as consequências da predominância do lirismo, caso fosse levada até os seus limites finais. Mas tal não se dá: o 'lirismo' está relacionado em tensão com a 'arte', não se encontra em oposição irredutível. “ (Lafetá, 2000 p. 173)

O crítico ainda ressalva que essa afirmação pode ser facilmente encontrar na própria Escrava, ensaio no qual Mário afirma que "lirismo não é poesia" e Lafetá complementa

E não o é por faltar a arte, por faltar o procedimento especificamente estético, a organização do moto lírico. A técnica é uma complementação necessária do lirismo, Mário de Andrade o sabe perfeitamente; por isso, também jamais afirmaria que os 'movimentos da subconsciência devem ser inteiramente respeitados', nem que 'versos e rimas devem ser livres', se tomarmos aí a palavra 'livres' no sentido absoluto que Roberto Schwarz parece lhe atribuir: a teoria do 'polifonismo' constitui uma sistematização que, embora justificada psicologicamente, possui um estatuto estético indiscutível, na medida em que é vista como uma processo de organização estrutural do poema.(Lafetá, 2000, p174)

Lafetá ressalta ainda a passagem de um binômio lirismo/arte, para um trinômio lirismo/arte/sociedade, citando ensaios como "Elegia de Abril", "A poesia em 1930" e outros ensaios do livro Aspectos da literatura brasileira. O debate em muito se assemelha ao que apresentamos na introdução deste capítulo. As colocações de Schwarz parecem com aquelas de Simon e Dantas, assim como a leitura de Lafetá lembra a leitura de Heloísa Buarque. Não deixa de ser curioso notar que pouco avanço houve na discussão de uma temática tão importante para a literatura brasileira quanto a relação entre arte e vida. Ainda mais curioso é que o debate sobre a literatura modernista ocorria no momento mesmo em que acontecia o fenômeno que ficou conhecido como poesia marginal.

De qualquer modo, não é nosso interesse discutir a pertinência das informações, mas apontar leituras, sobre as quais podemos supor que Cacaso, como professor de Teoria Literária e amigo de Roberto Schwarz, tenha tido acesso. Além disso, é possível afirmar que 
os dois críticos, Schwarz e Lafetá, principalmente o último, sintetizam, em seus textos, percepções que ressoam até os dias de hoje sobre a poesia modernista. Por esse motivo mesmo, destacaremos um elemento presente nesses ensaios de Mário e que não apareceu como elemento no debate: a liberdade, ou melhor, a busca pela liberdade.

Há diversos textos, entre cartas, ensaios e poemas, nos quais a preocupação com a liberdade aparece em Mário. A palavra é utilizada em diferentes acepções, como no prefácio interessantíssimo:

Minhas reivindicações? Liberdade. Uso dela; não abuso. Sei embrida-la nas minhas verdades filosóficas e religiosas; porquê verdades filosóficas, religiosas não são convencionais como a Arte, são verdades. Tanto não abuso! Não pretendo obrigar ninguém a seguir-me. Costumo andar sozinho. (ANDRADE, M., 2002, p. 22).

Aqui a liberdade é vista como um direito do indivíduo, é algo que não se impõe e com o que se deve ter cuidado, posto que em excesso pode escapar à própria Arte. Essa mesma leitura é repetida em conselhos como naquele que dá a Henriqueta Lisboa:

Mas lhe peço por favor quando retirar ou consertar alguma coisa, fazer sempre isso por sua exclusiva vontade e responsabilidade. [...] guarde sua liberdade inteira, por favor! Si concordar, muito que bem: jogue fora, conserte. Mas si não concordar, sustente. Só assim terei facilidade e despreocupação. [...] não se esqueça nunca que os seus versos e livros são exclusivamente de você. Muitas vezes um estado de idéias em que a gente está com paixão, um exemplo mau, um estado de sensibilidade, uma fadiga momentânea, até um calo doendo, pode me levar a um erro, a uma leviandade. Mas aí está você pra controlar tudo isto [...] (CARVALHO, 1991, p. 101).

O problema que decorre dessa postura será percebido por Mário anos mais tarde e será visto por muitos modernistas, da primeira e da segunda geração: o excesso de liberdade individual levou ao que ele chama de abstencionismo. Essa postura, como o próprio escritor paulista percebe mais tarde e como salienta Schwarz, pode levar a escrita ao silêncio.

A busca pela liberdade é um outro ponto de intersecção entre Mário e Cacaso, por isso nosso interesse. Contudo, nesse ponto em especial, o modernista parece não ter encontrado o equilíbrio entre os elementos que compõem a equação, ainda que ciente de todos os problemas que poderiam surgir, já que, ao que parece, nem sempre lirismo + arte = poesia, como o próprio Antonio Carlos de Brito percebe em alguns de seus escritos sobre a poesia dos $\operatorname{anos} 70$. 


\subsection{Oswald}

Outro escritor modernista para o qual a relação entre a arte e o cotidiano se mostra importante é Oswald de Andrade. É famoso o trecho do "Manifesto Pau-Brasil" que professa: "A poesia está nos fatos", mais do que isso: Os casebres de açafrão e de ocre nos verdes da Favela, sob o azul cabralino, são fatos estéticos.” É esse o parágrafo que abre o manifesto, que pode indicar uma defesa de uma poesia expressiva, algo reforçado pela adjetivação exagera, ligada mais a experiência vivida do que a técnica. Porém, alguns parágrafos abaixo, lemos o seguinte: "O trabalho contra o detalhe naturalista - pela síntese; contra a morbidez romântica - pelo equilíbrio geômetra e pelo acabamento técnico; contra a cópia, pela invenção e pela surpresa." O que vemos é uma posição ambígua, característica de Oswald em seus escritos, no que concerne ao papel da poesia na relação com a vida. O que em Mário é lirismo, passando pelo filtro da objetividade oswaldiana, vira cotidiano.

Assim como acontece com Mário, há um embate interessante entre dois ensaístas e, assim como em Mário, há a presença de Roberto Schwarz. Estamos falando de Haroldo de Campos, com o seu "Poética da Radicalidade" e "A carroça, o bonde e o poeta modernista", do crítico de Ao vencedor as batatas. Nesses dois ensaios temos os dois pólos de um espectro crítico, no qual outros estudiosos de Oswald vão se inserindo ${ }^{4}$. De um lado um poeta que trabalha expandindo limites, estabelecendo diálogos com outras artes, trazendo novos patamares para o fazer poético, de outro um poeta que tropeça em seu próprio projeto. A diferença pode ser vista na abertura dos textos, os quais apresentam a visão sobre a poética do poeta modernista, desenvolvendo-a no decorrer dos respetivos ensaios.

Schwarz coloca a questão da seguinte maneira:

Oswald de Andrade inventou uma fórmula fácil e poeticamente eficaz para ver o Brasil. A facilidade no caso não representava defeito, pois satisfazia uma tese crítica, segundo a qual o esoterismo que cercava as coisas do espírito era uma bruma obsoleta e antidemocrática, a dissipar, fraudulenta no fundo.(Schwarz, 1998, p.11)

\footnotetext{
${ }^{4}$ Ao dizermos que os outros críticos se inserem em um espectro crítico, não queremos desmerecer o trabalho de estudiosos de Oswald do porte de Maria Augusta Fonseca e Vinicius Dantas, pois ambos contribuíram muito para melhor compreensão da obra do poeta modernista, produzindo ensaios anteriores aos mencionados. Nossa posição indica apenas que, pelo fato dos textos lidarem com o sucesso e o fracasso de uma poética, de maneira bastante incisiva e sem espaços para ponderações, os críticos acabaram por se inserir nessa batalha
} 
A fórmula seria "a justaposição de elementos próprios ao Brasil-Colônia e ao Brasil burguês, e a elevação do produto - desconjuntado por definicção - à dignidade de alegoria do páis" (p.12) Haroldo, por sua vez, coloca-se contra a idéia de fórmula "Se quisermos caracterizar de um modo significativo a poesia de Oswald de Andrade no panorama de nosso Modernismo, diremos que esta poesia responde a uma poética da radicalidade. É uma poética radical." (p.7) A radicalidade do poeta modernista residiria

no campo específico da linguagem, na medida em que esta poesia afeta, na raiz, aquela consciência prática, real que é a linguagem. Sendo a linguagem, como a consciência, um produto social, um produto do homem como ser em relação, é bom que situemos a empresa oswaldiana no quadro de seu tempo. (Campos, 1978, p.7)

A empreitada oswaldiana é marcada pela ambiguidade. Muito dessa postura de Oswald, dessa busca por novos materiais vem da necessidade pelo novo, por outro lado há o artista que trabalha e reescreve o texto de maneira "flaubertiana" para retomar a comparação de Vinicius Dantas. É do mesmo crítico uma observação que bem resume a inconstância e a consequente incoerência de Oswald quanto ao trabalho com a escrita:

de início, o texto é posto em banho maria por um artista flaubertiano,
doentiamente empenhado no brilho da frase, amigo das excelências da
fatura; mais tarde, por uma circunstância qualquer e com afobamento, tudo é
desmanchado e o texto oswaldiano vem a lume prematuro (!).O criador que
se aplicara durante meses a fio a aprimorar um estilo, rendia-se ao fogo de
palha de uma experiência fresca, vivida anteontem. Se o caso da
mencionada re-escrita das Memórias Sentimentais é desse tipo, o que dizer
do capítulo "Os Antropófagos" de Serafim Ponte Grande, enfiado às pressas
em livro concluído, à maneira de um epílogo post-mortem? A invenção
oswaldiana não se ressentiu dessa política de extremos, antes pelo contrário
e surpreendentemente lhe deve o que possui de melhor. (Dantas, 1991, p.
200)

A presença da experiência cotidiana como matéria da poesia oswaldiana também é fruto dessa ambiguidade de um escritor que percebe o Brasil em Paris. Parece claro que a relação entre arte e vida nos textos oswaldianos tem um caráter diferente do que assume nos textos de Mário: ela não faz parte de uma reflexão sobre o estatuto da arte, mas está ligado a uma prática da escrita. Obviamente isso não quer dizer que não há prática em Mário ou que Oswald não exerça teoria, quer dizer apenas que há uma diferença de postura diante da arte. Cacaso parece combinar essas duas posturas. Não foge de teorizar e refina sua teoria pela prática. Ou seja, a questão é marioandradina, mas a fatura é oswaldiana. 


\section{Arte e vida em Cacaso}

A relação arte e vida em Cacaso é quase um dado crítico. A fortuna crítica de Cacaso e da poesia marginal como um todo coloca que essa volta ao cotidiano, ao coloquialismo é uma resposta ao ambiente cultural e uma rejeição da literatura anterior, sobretudo o concretismo e a geração de 45. É claro que esses são dados pertinentes e serão retomados no segundo capítulo. O clima de antiarte pairava sobre diversas manifestações artísticas, e a recusa da geração de 45 e dos concretos era manifesta claramente por críticos e poetas ligados ou não à poesia marginal.

Um dado que não aparece com frequência, contudo, é o viés modernista que existe nessa postura, e aqui falamos apenas de Cacaso. Os modernistas aparecem na fortuna crítica como referência para certos procedimentos literários, mas não como referência teórica, algo que, como mostramos, certamente eram. Por isso, nos centraremos em como se dá a presença modernista, a partir do que vimos nos itens anteriores, para analisar a relação entre arte e vida, a qual serve de base para a busca pela liberdade para a escrita.

Essa progressão mostramo-na no início do texto: Cacaso vê na relação arte e vida, tal qual estabelecida pelos modernistas, uma porta para a sua própria busca pela liberdade. $\mathrm{O}$ cuidado com um elemento como esse, que significa autonomia para a arte, mas não só isso, parece bastante claro em um contexto de repressão. Por esse motivo, há claras diferenças nas posturas de Cacaso e dos dois Andrades: o poeta dos anos 70 não é nem tão objetivo nem tão lírico no tratamento da matéria experimentada; a crença no progresso, já tinha sido vencida, como também foi vencida a construção de um projeto de nação;além disso, há o já citado campo cultural.

O fato é que extrairemos dos escritos de Cacaso essa relação. Um primeiro exemplo pode ser colhido ao debruçarmo-nos sobre dois textos, em que poetas de destaque nos anos 70, Chacal e Chico Alvim, são avaliados a partir da aproximação entre a poesia e a vida, entre o poético e o cotidiano. Trabalhada na poesia marginal, não transformou a poesia "em um veículo acrítico e desqualificado de expressão". Obviamente há diferença no alcance crítico não só entre esses dois poetas, mas também entre Cacaso e esses dois poetas. O procedimento geral, contudo, é bastante semelhante.

Comecemos com um trecho de um poema de Chacal: 
BUNDA MOLE DEDO-DURO TANTO TREME QUANTO ENTREGA

Cacaso descreve o procedimento utilizado nesse trecho da seguinte maneira:

"É fácil saber de que água Chacal bebeu: 'água mole em pedra dura...' etc. O ditado popular, com sua característica frase feita, seu tom moralizante e alegórico, é devorado e transformado noutro ditado, com outro raio de intenção, visando a outras imagens, num tom radical e de efeito desmoralizante. Que tipo de crítica é essa? De onde provém seu alcance?(...)" (Brito, 1997,p. 32)

A conclusão, resumindo os argumentos que se seguem à citação acima, é que há, na poesia de Chacal, um descompromisso, uma informalidade poética que resultam em uma atitude crítica. Interessa-nos, antes, o procedimento já que, como dissemos, o alcance crítico da poesia de Chacal é questionável e cabem algumas das críticas que Simon e Dantas fazem à poesia marginal: "dispõe formalmente seus elementos: o registro confessional e biográfico, a anotação irreverente do cotidiano, a nota bruta do sentimento, da sensação, do fortuito, são soluções poéticas que acabam impondo um padrão informal e antiliterário de estilização." 5 Dito de outro modo o bom resultado poético não é garantido pela simples reprodução da experiência, pois, muitas vezes, acaba por tornar-se simples procedimento estético, já que desacompanhado do movimento crítico. O próprio Cacaso reconhece essa possibilidade, no mesmo texto:

Esta informalidade que hoje reina em setores importantes de nossa ideologia de resistência, em nossa multiforme contracultura, facilita a difusão e a aceitação da crença de que uma vez que fazer arte e viver já não se distinguem, então a possibilidade de criar também já não supõe maiores capacitações, e todo mundo indistintamente é promovido a artista, o que é o mesmo que extinguir a espécie.(Brito,1997,p.28)

A observação não é feita especificamente sobre os textos de Chacal, mas podemos colher exemplos no texto que demonstram que a liberdade que Cacaso celebra, a relação com a arte e vida não é simplesmente individual: "estamos diante de uma atitude de desabafo e o valor do poema passa a depender menos da realização do que da sinceridade - valor moralque manifesta."; ou ainda "temos a impressão de que o poema fica aquém da complexidade de tratamento que sua matéria solicita." Por fim o crítico dá um exemplo de sua concepção de liberdade: "a liberdade é para ser encarnada agora e não para ser uma meta futura. como na poesia missionária de esquerda, ou simplesmente sufocada e administrada, como nos auto-

\footnotetext{
${ }^{5}$ É um pouco difícil entender de maneira exata o que os dois críticos querem dizer com "antiliterário". Parece que é apenas uma confirmação das leituras feitas até então sobre a poesia marginal, com o valor invertido.
} 
intitulados grupos de vanguarda." A oportunidade de, mais uma vez, usar a discussão sobre a liberdade para se afastar de outros tipos de poesia não é desperdiçada.

A percepção geral de Cacaso quanto aos textos de Chacal é que, entre erros e acertos, a vitória é da liberdade conquistada pela relação poesia e vida. O crítico parece supor a fragilidade desses textos e termina assim seu artigo:

"Sobre o valor propriamente literário da poesia de Chacal, a questão do seu envelhecimento ou duração, sua importância e lugar dentro do quadro mais geral de nossa poesia, tudo isso depende em parte de perspectiva temporal, o que não nos é possível por agora." 1997, p.43

Movimento diferente é realizado na leitura da poesia de Chico Alvim ${ }^{6}$. O movimento crítico é completo e também recebe a atenção de Cacaso. Tomemos como exemplo a análise que é feita do seguinte poema de Alvim, do livro Passatempo, de 1974:

\author{
Almoço \\ Sim senhor doutor, o que vai ser? \\ Um filé mignon, um filezinho, com salada de batatas \\ Não: salada de tomates \\ E o que vai beber o meu patrão? \\ Uma caxambu
}

A citação é longa, mas explicativa:

O segredo de um poema como este parece estar na quantidade de experiência que acumula, algo que surge na forma de hábito formado, de costume. Como no gesto social do garçom, simpático, mas também submisso e instrumentalizado. O estereótipo colhido ao vivo, no seu nascedouro. A cena é muito íntima, passa-se entre duas pessoas. Mas a mediação social, com os seus lugares-comuns, seus gestos cristalizados, sua face reconhecível, dão generalidade e impessoalidade ao poema. Existe toda uma história contida neste 'sim senhor doutor' e neste 'meu patrão'. Algo como a confirmação de um hábito, sua sedimentação, numa síntese de relacionamento onde tudo é transparente: o garçom é o garçom, o freguês é o freguês. Ambos têm os seus comportamentos e as suas falas respectivamente adequados à posição social de cada um. É de se notar o aspecto de transparência do poema: não há qualquer mediação retórica, o apego a qualquer automatismo estilístico, nada: a cena é mostrada ao vivo, diretamente, com economia de meios, apenas o suficiente que dê para o reconhecimento cordial da situação. (Brito, 1997,p.310-311).

O enunciado é exposto de maneira crua. De acordo com Cacaso, essa exposição sem mediação geraria inclusive um questionamento sobre a idéia de autoria. Explicando melhor: a

\footnotetext{
${ }^{6}$ Viviana Bosi aponta três linhas na poesia de Alvim, estamos trabalhando com a terceira e quando falamos sobre a poesia de Chico Alvim estamos nos referindo a esse terceiro tipo de poemas.
} 
começar do título o poema funciona como um retrato; há um recorte de determinado diálogo que em sua situação enunciativa original nada teria de importante. Deslocado, contudo, começam a ter destaque as formas de tratamento como "meu patrão" e "doutor" e um diálogo aparentemente inocente vai mostrando o jogo de poder no diálogo entre garçom e cliente. Mostra também as estratégias do garçom que, como bem aponta Cacaso, "não se limita a ser correto: é solícito, além de velhaco."

No mesmo ensaio, há uma discussão sobre a relação arte e vida:

"O poema curto dá a impressão, e há nisso um fundo de inverdade, de que é de fácil realização, abolindo as noções de competência e especialização literárias. E se postando, democraticamente, ao alcance dos pretendes. Quem é que não é capaz de registrar, sem compromisso e pretensão, qualquer coisa vivida ou observada, tudo ao sabor da ocasião e sem maiores delongas? Descobre-se que a poesia existe em tudo, e tudo pode ser poesia. É claro que, num momento desses, do ponto de vista da poesia em si mesma, é natural que haja um rebaixamento do nível de qualidade artística. Uma desqualificação da arte. Mas essa desqualificação vai ter um peso muito relativo e um valor tático, e em certo sentido passa a papel secundário. O impulso geral de desindividualização da autoria cumpria e cumpre uma função-chave, de alcance na poesia brasileira: a abertura para a experiência emergente, para a atualização da experiência. (Brito, 2000, p.324)

Algumas diferenças de postura em relação aos dois modernistas elencados ficam mais claras: há uma defesa da desindividualização, portanto não podemos aproximá-lo da defesa do lirismo e do aspecto psicológico tal como faz Mário; por outro lado essa desindividualização leva a uma defesa da abertura para a experiência, para a atualização da experiência, o que carrega uma subjetividade, portanto não se pretende objetiva como a poesia oswaldiana. A relação arte e vida em Cacaso chega a uma parodoxal defesa da subjetividade sem individualidade.

É a busca pela criação de uma espaço discursivo de subjetividade. É uma prática da escrita que pode ser resumida na seguinte afirmação, do mesmo ensaio: "Do ponto de vista do poeta, o viver leva ao escrever; do ponto de vista do leitor, o ler leva ao viver."

A diferença entre Alvim e Chacal é que eles trabalham de formas diferentes com essa subjetividade desindividualizada. O primeiro busca no outro essa relação, o segundo cria um "eu" que, para falar com Flora Sussekind, "não é idêntico àquele dos depoimentos, biografias e memórias, ou seja, é também um "eu” desindividualizado. 
Um último exemplo antes de chegar aos poemas do próprio Cacaso. Em um artigo sobre o poeta Charles, destaca-se a seguinte afirmação, que vem confirmar algumas das leituras que propusemos até o momento:

O livro Creme de lua, a começar pelo título e pelo desenho da capa, participa deste tipo especial de romantismo que já não crê em si mesmo, que sabe que suas imagens estão desgastadas, que sua aura está em estado avançado de decomposição, e que uma atitude nova está sendo exigida. Ora, desde o momento em que o poeta perde o interesse pela forma fixa e estereotipada, pelo jargão poético já legitimado, apenas uma atitude pode reconduzi-lo a uma consistente renovação de sua capacidade expressiva: voltar a frequentar a matéria densa e complexa da experiência vivida por ele e seus contemporâneos (Brito, 1997, p.217)

Mais uma vez vemos a combinação entre a poesia e vida para dar liberdade ao poeta. Importante aqui marcar, mais uma vez, a diferença entre Cacaso e os modernistas. A poesia deve buscar sempre o "direito de errar", ou seja, a liberdade de experimentação, também defendida por Mário, mas que no modernista não leva a autonomia da arte, pelo contrário, acabou por exigir, em suas últimas palestras e ensaios, um engajamento do artista.

A procura por elementos de comunicabilidade, da renovação da capacidade de expressão sem que se perdesse o movimento crítico, pelo "direito de errar" aparecia também em textos poéticos de Cacaso. Em nossa leitura, essa busca por uma poética mais "solta", que foge da institucionalização é gradual e não é regular. Ou seja, há uma aprofundamento nessa busca de uma obra para outra, mas isso não significa que todos os poemas de um livro como Beijo na boca, em nossa opinião aquele que melhor mostra esse lado de Cacaso, se adequem a esse tipo de poética.

A relação com os modernistas aparece também na obra poética. Um exemplo interessante desse diálogo pode ser retirado do livro de 1978, o já mencionado $N a$ corda bamba:

\section{Façanha}

Tomou muita cachaça

Ficou lúcido

Quis se matar

Em um primeiro momento não há muito o que falar do poema, parece retratar uma situação quase banal de um homem bêbado que quer se matar. Não sabemos qual a origem da história, se ela é inventada, se ela foi ouvida, se ela foi lida em um jornal. Narrada de forma 
simples e direta, a história é completamente impessoal, sendo contada em terceira pessoa, sem referências espaciais. Poderíamos deduzir que se trata de uma pessoa de classes sociais mais baixas, pois toma cachaça e não whisky. Ainda assim, não é uma afirmação que possa ser feita de forma categórica, pois senhores de engenho também bebem suas cachaças. Não sabendo se é um ambiente rural ou urbano, se é em uma capital ou em uma pequena cidade, se é um paulista, um baiano ou um carioca, pouco podemos afirmar com toda a certeza.

A banalidade do poema é reforçada pela sua descartabilidade. Certamente não é um grande poema de Cacaso e sua força reside justamente no fato do retrato sem mediação alguma, o qual, diferente do que ocorre com Alvim, não constrói um movimento crítico, posto que se fecha em si mesmo. Há uma necessidade de despoetização nesses versos que parece forçada.

Em um segundo momento, contudo, podemo parar e encontrar semelhanças com um outro poema. Podemos abrir um livro de um poeta pernambucano modernista e encontrar o seguinte título: "Poema tirado de uma notícia de jornal". O poema é bastante famoso, mas cabe reproduzi-lo para reforçar que o leitor ele próprio note a semelhança:

\section{Poema tirado de uma notícia de jornal}

João Gostoso era carregador de feira livre e morava no morro da Babilônia num barracão sem número

Uma noite ele chegou no bar Vinte de Novembro

Bebeu

Cantou

Dançou

Depois se atirou na lagoa Rodrigo de Freitas e morreu afogado.

É de Bandeira o poema. E as diferenças entre este e o de Cacaso são tão visíveis quanto as semelhanças. As referências espaciais, se não definem o personagem, dão a ele uma individualidade: sabemos que ele era chamado de "João Gostoso", morava no morro da Babilônia, embebedou-se no bar Vinte de Novembro e morreu na lagoa Rodrigo de Freitas, morador do Rio de Janeiro, portanto. A diferença principal, contudo, está no título. Davi Arriguci faz o seguinte comentário sobre o poema:

A força simbólica do achado de Bandeira, que com ele arrasta o bloco de uma realidade muito mais ampla e complexa, demonstra a autonomia da forma significativa obtida pelo poema, ao desvencilhar-se do jornal e do caráter circunstancial da notícia de onde se originou. (Arrigucci, 1999, p.108) 
Certamente há uma autonomia da forma poesia, embora possamos questionar se o texto se desvencilha de fato do jornal, posto que no título há o anúncio de onde se buscou a matéria-prima. Anuncia ainda que sua intenção é poetizar aquele matéria bruta que não poderia, em si, ser poesia. O texto está para sempre ligado a forma jornalística, pois essa relação é estabelecida no título.

Não seria demais dizer que Cacaso buscou esse poema como ponto de partida para seu próprio poema, fazendo o movimento de busca da matéria-prima. Heloísa Buarque, em entrevista publicada na revista Inimigo Rumor, expõe o seguinte aspecto sobre o mineiro e sua relação com os modernistas:

Para responder especificamente sua ultima pergunta: Cacaso, no maior rigor, estudava sim e seríssimamente cada um dos modernistas separadamente, especialmente Bandeira, seu predileto, sobre o qual tinha análises e insights sapientíssimos.(Hollanda, 2000, p.102)

Começa a se desenhar a diferença entre a postura diante da escrita que Cacaso exerce e aquela exercida pelos modernistas. $\mathrm{O}$ poeta avança mais um passo na trajetória iniciada por Bandeira. Perde-se a necessidade de objetivar a matéria cotidiana, algo que ocorre tanto em Bandeira quanto em Oswald, e em outros poetas modernistas, mesmo que se corra o risco de torná-la inócua. A poesia quando livre pode tornar-se livre até da escrita ela mesma.

Lendo um poema de Cacaso, podemos perceber com mais clareza essas diferenças de postura que aparecem em um poema do livro Grupo Escolar, de 1974:

\section{JOGOS FLORAIS}

Minha terra tem palmeiras onde canta o tico-tico. Enquanto isso o sabiá vive comendo o meu fubá.

Ficou moderno o Brasil ficou moderno o milagre: a água já não vira vinho, vira direto vinagre.

II

Minha terra tem Palmares memória cala-te já.

Peço licença poética 
Belém capital Pará.

Bem, meus prezados senhores

dado o avançado da hora

errata e efeitos do vinho

o poeta sai de fininho.

(será mesmo com 2 esses

que se escreve paçarinho?)

O movimento crítico do poema resulta da combinação de um diálogo com situações enunciativas distintas, deslocadas de seu contexto original e a referência ao cotidiano, passando, neste texto em específico, pela citação histórica. As referências passam por Gonçalves Dias e Oswald de Andrade, o "milagre econômico” brasileiro e a bíblia.

O título do poema também ele é uma referência: remete a uma competição de Trovas, poemas compostos de estrofe de quatro versos, todos em redondilha maior, com rimas cruzadas ou alternadas. Há, no entanto, uma subversão da forma: a trova é apenas de uma estrofe, teríamos, portanto, quatro trovas e não duas. Além disso, a última estrofe tem apenas dois versos, quebrando a estrutura em quadras; o fato dela aparecer entre parenteses indica uma espécie de adendo, um complemento ao que já foi dito.

A divisão do poema em duas partes corresponde a uma mudança no tom. Se a citação que abre a primeira parte é de um famoso poema celebratório, a "Canção do Exílio", do poeta romântico Gonçalves Dias, a presença marcante na segunda parte é Oswald de Andrade, o poeta modernista, ainda que em uma releitura da poesia de Gonçalves Dias, que é a referência principal, percorrendo todo o poema.

A idéia de exílio, na primeira parte, ganha outra dimensão quando retomada nos anos 70 em plena ditadura, perdendo o tom saudosista e ganhando um tom melancólico. O texto romântico é usado para criticar, pois o sabiá, metáfora para o brasil, come toda comida do tico-tico, retomando a figura do povo, provavelmente. Estende-se a crítica com a ajuda de referências bíblicas: a famosa passagem quando Jesus transforma a água em vinho, realizando um milagre, é usada para criticar o "milagre econômico" dos anos 70 que de milagroso não teria nada; por mais modernos que seja, esse milagre, quando do momento da partilha, já é vinagre, ou seja, na divisão das riquezas geradas pelo avanço da economia brasileira, fica para a população a parte "estragada" do vinho, o vinagre. É o que se convencionou chamar de modernização consevadora. $O$ futuro não aparece de forma 
esperançosa, pelo contrário, reforçada pela melancolia do exílio causado pelo golpe, há uma promessa que, sempre anunciada, não se cumpre. A irreverência de Cacaso funciona tanto em seu sentido mais usual, de comicidade, quanto na ausência de reverência.

Ainda quanto às referências românticas e ao texto de Gonçalves Dias, os versos são redondilhas maiores, com dois versos em oitava. Os versos em redondilha remetem tanto a cultura popular, quanto a cultura escrita, no caso as trovas a que faz referência o título: Jogos Florais são uma competição de Trovas, poemas de apenas uma estrofe, sempre de quatro versos heptassílabos com rimas cruzadas ou alternadas. As trovas de Cacaso não são todas elas, escritas de acordo com o bom manual de versificação; deveriam ser quatro e não duas como indicam os números acima dela para que fossem monoestróficas, há dois versos de oito sílabas e as rimas não seguem um padrão. Essa referência, trazida pelo título, a uma forma fixa, que no decorrer do poema não encontra sua confirmação é outra maneira de descumprir as promessas anunciadas.

Na segunda parte, que começa com uma referência a Oswald, o tom aproxima-se ainda mais do coloquial, como que seguindo as lições modernistas. Se na primeira parte é o futuro que nunca se cumpre, na segunda parte é a memória que não pode ser resgatada. Há, contudo, uma contradição performativa, uma contradição que parece ser própria do período: a memória não pode ser resgatada, no entanto ela já foi enunciada, ou seja, ela já foi resgatada. A relação entre autonomia e repressão, tão tensa neste poema, parece ser uma característica constitutiva do período ditatorial no Brasil, algo já explorado por Roberto Schwarz em famoso ensaio que será retomada adiante. Ainda mais interessante é a maneira com que a repressão aparece, na forma de um aluno bem comportado e exemplar, que, pedindo licença (poética é bem verdade), enuncia, orgulhoso, a capital do Pará. Poderia ser mais uma crítica ao academismo vazio, que tanto horror causava em Cacaso.

Essa aproximação tensa entre autonomia e repressão reaparece no contraste entre a cultura letrada e a cultura oral, que também percorre todo o poema, seja na referência aos românticos e aos modernistas, a Bíblia e ao milagre econômico, a escola e ao quilombo, e explode na última estrofe. Ao se questionar se passarinho é com dois esses, escrevendo "paçarinho", com o cedilha, a relação entre fala e escrita ganha nova dimensão. É quebrada e preeminência da cultura escrita, restando a ela o questionamento. Contudo, não é possível fazer a afirmação de que a cultura oral sai vencedora, já que o poema só existe como materialidade por meio da escrita. Mais uma vez, Cacaso joga com uma tensão não resolvida. 
Esta Parece-nos ser a característica marcante do período, afetando diretamente a produção marginal. Eles tem de lidar com um embate entre a poesia engajada do CPC e seu Violão de Rua e a poesia de vanguarda dos concretos e neoconcretos. Tem de lidar com um campo que apresenta diversas características de um campo autônomo, mas ainda sofre com a repressão. Lidam com um mercado editorial já constituído, mas com a dificuldade de fazer circular suas obras. Há reflexos de todas essas questões nos melhores textos marginais.

São essas características peculiares do campo literário, que nos ajudarão a explicar parte dessa diferença entre Cacaso e os modernistas, que lhe eram tão importante. É preciso compreender melhor qual era o "espírito da época" dos marginais e dos modernistas, para que possamos entender essas diferenças de procedimentos técnicos entre essas duas gerações. 


\section{As diferenças: em busca de um campo (literário) perdido}

\section{O que está por vir?}

Como mostramos no primeiro capítulo, a relação entre arte e vida é um ponto importante no estudo da poética de Cacaso. Não por acaso, um dos trabalhos de grande destaque sobre a poesia dos anos 70 foi de um sociólogo, chamado Carlos Messeder Pereira, que em seu trabalho, Retrato de Época, utiliza o conceito de campo para estudar o relacionamento entre arte e vida.

Por meio do estudo do campo podemos, por exemplo, compreender as diferentes funções exercidas por Cacaso tais como poeta, crítico, letrista, professor e "agitador cultural. Ainda quanto ao campo, podemos entender como se formaram e se cristalizaram algumas das contradições constitutivas da obra de Cacaso, tais como as que vimos ao final do capítulo1, dos marginais e talvez do próprio Brasil, com a passagem dos anos 20, ainda na república, mas em um campo literário sem autonomia alguma, para os anos 30, com a ditadura Vargas, mas o começo da conquista da autonomia para o campo. Ou seja, mais uma vez, a contradição entre a liberdade e a repressão.

O conceito de Campo será útil, ainda, para que fique clara, principalmente, no caso da poesia dos anos 70, a importância do espírito da época no estudo dos textos. Ideias como o poemão fazem mais sentido se lembrarmos do silêncio que imperava devido à repressão; a 
dessacralização da arte e a postura quanto ao público se tornam mais compreensíveis se considerarmos a situação da arte como um todo e não apenas a literatura.

Além disso, aproximando os campos do modernismo e dos anos 70, poderemos tornar mais claras as diferenças não apenas na postura, mas nos impasses que se colocam para essas duas gerações. Desse modo, poderemos aprofundar o que iniciamos no capítulo anterior.

\title{
2. O que são campos literários?
}

A teorização do conceito de campo vem do sociólogo francês Pierre Bourdieu. Ele assim o define:

\begin{abstract}
Os campos se apresentam à apreensão sincrônica como espaços estruturados de posições (ou de postos) cujas propriedades dependem das posições nestes espaços, podendo ser analisadas independentemente das características de seus ocupantes (em partes determinadas por elas).(...) A estrutura do campo é um estado de relações de força entre os agentes ou instituições engajadas na luta ou, se preferirmos, da distribuição do capital específico que acumulado no curso das lutas anteriores, orienta as estratégias ulteriores. Esta estrutura, que está na origem das estratégias destinadas a transformá-la, também está sempre em jogo: as lutas cujo espaço é o campo têm por objetivo o monopólio da violência legítima (autoridade específica) que é característica do campo considerável, isto é em definitivo, a conservação ou a subversão da estrutura da distribuição do capital específico. ${ }^{7}$
\end{abstract}

O campo é um espaço, não necessariamente físico, em que ocorrem as relações entre os indivíduos, grupos e estruturas sociais, com uma dinâmica própria que obedece a leis próprias, animadas sempre pelas disputas ocorridas em seu interior, aquilo que Bourdieu chama de monópolio da violência legítima, uma posição que, muito provavelmente, ele retira da idéia de micropoder do Foucault. A forma do campo não é fixa, por esse motivo, quando falamos, por exemplo, em campo literário, a lógica do campo francês será diferente do brasileiro, ainda que possam compartilhar agentes e estruturas. Mais do que isso, o campo literário brasileiro será diferente nos anos 20 e nos anos 70 do século XX, já adiantando nossa temática.

No Brasil há outro conceito, surgido na literatura, mas aplicável à cultura como um todo, que é a ideia de "sistema", fruto de reflexão de Antonio Candido, e apresentada no clássico Formação da Literatura Brasileira. A diferenciação se faz necessária pois há no

\footnotetext{
${ }^{7}$ BOURDIEU, Pierre. Questões de sociologia. Rio de Janeiro: Marco Zero, 1983. p. 89-90.
} 
Brasil um uso da ideia de sistema literário ${ }^{8}$, como se fosse um equivalente do conceito de campo. Fortemente pautado no conceito de nação e que tem o tripé escritores/editores/leitores como essencial para sua constituição, Candido assim define o que seria sistema:

a existência de um conjunto de produtores literários, mais ou menos conscientes do seu papel; um conjunto de receptores, formando os diferentes tipos de público sem os quais a obra não vive; um mecanismo transmissor, (de modo geral, uma linguagem, traduzida em estilos), que liga uns a outros(Candido, 2007, p.25).

Ainda segundo Candido, "o início de nossa verdadeira literatura" estaria localizado "na fase arcádica(...) graças à manifestação de temas, notadamente o Indianismo, que dominarão a produção oitocentista". Quanto ao campo literário, podemos dizer que ele está em funcionamento, mas não consolidado: não temos todos nossos agentes e instituições atuando, a própria literatura não se consolida como instituição até, pelo menos, meados da década de 70, como procuraremos demonstrar mais à frente. Além disso, há o forte conceito de formação, onipresente na crítica brasileira em meados do século XX, a sustentar a ideia de "sistema". O conceito de formação pressupõe um acabado, um momento em que o sistema está pronto, algo que para a ideia de campo é inadequado, pois podemos falar apenas em uma conquista da autonomia e não de um repouso ou de uma consolidação do campo.

Outra diferença importante é o peso do indivíduo na construção do sistema. É preciso que haja produtores literários "mais ou menos conscientes do seu papel”. Bourdieu, por outro lado, busca minimizar exatamente o papel do que se costumou chamar de consciência, minimizando a função do indivíduo na constituição do campo e jogando luzes nas instituições e no que chama de agentes, indivíduos vistos pela função que ocupam no campo.

Os anos 70, aliás, foram marcados por diversas teorias que procuravam apagar ou ao menos minimizar o papel do indivíduo, procurando objetivar até a função-sujeito, para falar como Foucault. No Brasil esse apagamento do sujeito se deu através das teorias

\footnotetext{
${ }^{8}$ É possível perceber um movimento que utiliza o conceito de sistema com o mesmo peso do conceito de campo literário.Podemos citar alguns artigos recentes como "HISTÓRIA, SISTEMA LITERÁRIO E SOCIEDADE NA VERSÃO FOLHETINESCA DE QUINCAS BORBA" de Luiz Antonio Silva, publicado na revista Matraga número 23, ou "REGIONALISMO E SISTEMA LITERÁRIO BRASILEIRO”, de Humberto Hermenegildo Araújo, publicado nos anais do encontro de 2007 da Abralic.
} 
estruturalistas, as quais renderam polêmicas interessantes, envolvendo até mesmo alguns poetas dos anos 70, como Cacaso e Ana Cristina César ${ }^{9}$.

Há por fim, uma diferença marcante: o campo pressupõe um estudo processual e não, ao menos não necessariamente, analítico; enquanto o contrário ocorre com o sistema. Dito de outro modo, o sistema, na elaboração conceitual de Candido, não sofre mudanças, o campo sim; sendo nossa intenção explorar as mudanças que ocorreram nas condições de produção, circulação e recepção entre os modernistas e os marginais, o estudo do campo torna-se mais adequado.

\section{O campo literário modernista}

\subsection{A busca da autonomia}

Há uma divisão, já consagrada na crítica, entre o que seriam dois tempos modernistas: o primeiro tempo, a fase heróica, com predomínio da poesia, que vai de 1922 até 1930; a segunda fase, de consolidação, que se confunde com o regionalismo, há o predomínio da prosa, e vai de 1930 até meados de 45. Essa divisão remete a uma construção que nos interessa: o primeiro momento seria a busca por um ideal na literatura que só encontraria seu representante político na geração seguinte. Candido aponta essa divisão no prefácio do livro de Lafetá 1930: a crítica e o modernismo : “A proposta de Lafetá (desde logo incorporada ao elenco dos nossos estudos literários) se baseia no intuito de mostrar de que maneira o Modernismo se desdobrou como passagem do 'projeto estético' dos anos de 1920 ao 'projeto ideológico’ de 1930” (Lafetá, p.8)

O próprio Lafetá, contudo, coloca a questão de maneira um pouco distinta: "Nosso ponto central é o fato de que a década de 30 assiste, sob o influxo e o empuxo da luta político-ideológica, à dissolução dos princípios estéticos modernistas.” E continua, deixando mais clara a sua afirmação: "uma nova consciência dos problemas sociais instalava-se no país e um novo projeto ideológico engendrado pelos nossos intelectuais, entrava em choque com as pesquisas de linguagem e a inventividade verbal que marcaram o Modernismo". (p.255) Justamente o que parece voltar, ao menos na visão de Cacaso, à poesia nos anos 70 .

A divisão entre dois tempos modernistas certamente não foi uma proposta crítica de Lafetá ou mesmo de Candido ${ }^{10}$, os próprios escritores buscavam essa diferenciação, mas a

\footnotetext{
${ }^{9}$ Isso nos faz supor que o chamado excesso de subjetivação da poesia marginal, poderia ser uma resposta a essas teorias que buscavam apagar o sujeito na análise crítica.
} 
leitura de que a ruptura se deu quase como um abandono de conquistas estéticas da geração anterior, o que poderia até mesmo explicar a geração de 45, é uma leitura de Lafetá. O crítico percebe, por exemplo, que a crítica feroz que Mário faz ao modernismo está relacionada à tentativa de equilibrar as conquistas estéticas com as necessidades sociais.

Há outras diferenças entre as duas gerações modernistas, que vão além das posturas literárias. Não é por acaso, por exemplo, que muitos dos escritores do primeiro tempo modernista tiveram que bancar do próprio bolso as primeiras edições de seus livros, em alguns casos todas as edições, não havia mercado editorial. Tampouco é acaso que intelectuais como Mário de Andrade, Oswald de Andrade, Manuel Bandeira, Raul Bopp tenham exercido atividade crítica, já não havia uma instância clara de legitimação e eles precisaram botar a mão na massa. Esses elementos, como o mercado editorial, universidades que criassem uma "mão de obra" especializada surgem apenas a partir da década de 30.

É também nesse momento, retomando a leitura já cristalizada de Candido e Lafetá, que o aspecto político do movimento ganha corpo, não só pela filiação aos partidos, algo que já ocorre na década de 20, mas pelo fato de os intelectuais ocuparem espaços no governo Vargas. A relação já foi estabelecida por Sérgio Miceli, no livro Intelectuais à brasileira, e reforçada por Randal Johnson, no artigo "A dinâmica do campo literário brasileiro (193045)”, mas vale a pena retomá-la. Como colocado pelos críticos, dizer que há uma relação entre o Estado Novo e os intelectuais não significa que aquele determine estes. Para retomar Johnson:

No caso específico do Brasil, onde a produção cultural tem-se desenvolvido à sombra ou dentro de parâmetros autorizados pelo Estado, as relações com o(s) poder(es) constituído(s) devem ser consideradas como parte das múltiplas afiliações da literatura. Isso não quer dizer que os intelectuais ou os escritores sejam 'contaminados' em sua ligação com o Estado; que a literatura esteja necessariamente a serviço do Estado; ou que esteja diretamente sujeita a determinações econômicas; ou, ainda, que simplesmente 'reflita' as ideologias políticas externas. Ao contráio, a literatura e a prática literária brasileiras participam e expressam, de várias maneiras, as clivagens que caracterizam o pensamento da elite social de modo geral. (Johnson, 1995, p.167)

\footnotetext{
${ }^{10}$ Apenas como curiosidade, Alceu de Amoroso Lima, em texto aparentemente não consultado por Lafetá, publicado na revista Lanterna Verde, afirma que "o Modernismo preparou um renascimento literário pósmodernista (p.90)", dando a enteder que os membros da revista se viam em outro período literário.
} 
Podemos acrescentar que era preciso, na busca pela autonomia do campo literário, ocupar espaços naquelas que eram as instâncias de legitimação. Essa relação com o Estado pode ser explicada também por esse viés. Para que a institucionalização da literatura ocorresse, seria preciso criar as próprias instituições que seriam responsáveis por dar sustentação a um campo literário autônomo, como as universidades, bibliotecas e institutos de pesquisa.

Até então, o escritores precisavam participar de diversos debates, pois o discurso literário circulava por entre outros discursos. Não havendo separações claras entre os campos culturais, pois não havia um espaço discursivo definido, a figura do literato, do intelectual que circulava entre diversos campos do saber, ainda era possível, justamente porque os campos culturais ainda não haviam conquistado sua autonomia. Nos anos 70, por outro lado, havia tido início a era dos especialistas, não sendo mais possível à literatura ter o mesmo alcance de antes.

Pelo mesmo caminho de leitura podemos explicar o porquê da construção de projetos literários aliados a projetos políticos: assim como era preciso criar as instituições para que a literatura pudesse se institucionalizar, para que houvesse uma literatura nacional, era preciso que houvesse uma nação. Como construir uma literatura moderna, em um país que nada tinha de moderno? Por isso a literatura vinha acompanhada de uma visão sobre o país. Essa dupla função da literatura, estética/ética, será o padrão até o concretismo.

Ainda no campo das instituições necessárias à construção de um campo literário autônomo, o mercado editorial é elemento que se constitui de fato apenas nos anos 30, com o claro exemplo da editora e livraria José Olympio. Aqui podemos estabelecer uma diferença importante entre os poetas dos anos 70 e os poetas dos anos 20. Estes bancavam as edições do próprio bolso porque não havia editoras em número suficiente, talvez não houvesse mesmo um mercado de consumo, que suportasse tantos livros de poesia ${ }^{11}$, isso apesar de ocuparem os espaços de prestígio no campo literário; aqueles escreviam em um momento em que não apenas o mercado editorial já era forte, mas houve o boom das editoras universitárias, além do aumento nas finanças das editoras com a política do livro didático do Governo Militar conhecida como Colted e, contraditoriamente, estavam a margem do mercado no que concerne a poesia e no centro quanto aos espaços críticos. Há, em ambos os períodos,

\footnotetext{
${ }^{11}$ A título de comparação, um livro de Manoel de Barros, um dos poetas mais lidos no Brasil costuma ter tiragem inicial de 10 mil exemplares.
} 
contradições, mas as diferenças históricas são enormes. A contradição modernista estava diretamente relacionada a uma contradição da formação do campo. A contradição que os escritores enfrentaram nos anos 70, embora estivesse ela também relacionada ao campo, trazia para a literatura aquilo que chamamos de contradição formadora, que aqui se mostra no descompasso entre o espaço discursivo já construído e sua impossibilidade material; caminhos que só começarão a se encontrar nos anos 80. Não são, portanto, as mesmas condições de circulação e colocar essas duas situações tão distintas, não apenas nas condições históricas, mas nas condições materias, no mesmo patamar como uma questão brasileira é ignorar diferenças substanciais entre essas duas gerações na postura diante da literatura.

Há uma caracterização interessante de Vinícius Dantas, em artigo sobre Oswald de Andrade, que resume o grau da mudança que ocorreu de um período a outro até aqui:

\begin{abstract}
A formação do Modernismo ocorreu no círculo de uma cultura provinciana, na órbita oficialista de redações dos principais diários, gabinetes políticos, alguns raros salões e grupamentos novos de artistas, boêmios e intelectuais. Cabe-nos lembrar a peculiaridade do meio literário de São Paulo, que já possuía organicidade e densidade próprias, com características diferentes das de outras cidades brasileiras. A literatura produzida aí estava articulada a seu próprio público, em cujo crescimento influíam decerto os avanços educacionais do Estado, o volume do mercado editorial e a modernização de sua imprensa. Baseada no padrão de comunicabilidade românticoparnasiano, essa literatura se torna mais comercial e permite que práticas e gêneros os mais ornamentais adquiram uma funcionalidade social diversa. Contudo, São Paulo não conseguia corresponder à auto-imagem moderna e progressista do seu poder econômico, diferenciando-se afinal da belle époque carioca. Esse é o tamanho paulistano do debate cultural que influiu na eclosão do Modernismo, mas que tem ficado à sombra, seja porque as animosidades dentro do grupo, crescendo com os anos, jogou silêncio sobre essa fase, seja porque a repercussão nacional do movimento em contexto mudado tendeu a recalcar a ambiência das origens. É por isso que se conhece tão pouco desse período e menos ainda se sabe distinguir as feições novas que estavam a se esboçar no mormaço paulista de ecletismos. (DANTAS, 2000, p.9)
\end{abstract}

$\mathrm{O}$ afastamento desse provincianismo deu-se, curiosamente, com um movimento que ficou marcado, ao menos de modo geral, como regionalista. Foi apenas na década de 30 que, sistematizadas algumas das questões levantadas pelos intelectuais nos anos 20, o movimento adquiriu maturidade. Isso seria reforçado, segundo Candido, pelo fato dos escritores não voltarem seus olhos para modelos estrangeiros e passarem a adotar referências nacionais: 
Um estágio fundamental na superação da dependência é a capacidade de produzir obras de primeira ordem, influenciada, não por modelos estrangeiros imediatos, mas por exemplos nacionais anteriores. Isto significa o estabelecimento do que se poderia chamar um pouco mecanicamente de causalidade interna, que torna inclusive mais fecundos os empréstimos tomados às outras culturas. No caso brasileiro, os criadores do nosso Modernismo derivam em grande parte das vanguardas européias. Mas os poetas da geração seguinte, nos anos de 1930 e 1940, derivam imediatamente deles - como se dá com o que é fruto de influências em Carlos Drummond de Andrade ou Murilo Mendes. (Candido, p.153)

Candido, aliás, sempre se preocupou com questões do campo literário, sem contudo utilizar tal conceito. Em ensaios e artigos dos mais variados nosso grande crítico literário preocupou-se em construir, ou reconstruir, o espírito do período modernista, discutindo o ambiente político, as relações pessoais e literárias, o alcance dos projetos literários e políticos. Randal Johson, em seu artigo sobre o campo literário, retoma várias das reflexões que Candido estabelece no artigo "A Revolução de 1930 e a cultura" para defender a ideia de campo literário autônomo.

Entre as observações mais próximas, Randal Johnson afirma que no perído entre 1930 e 1945 foi conquistada a autonomia do campo literário brasileiro. Antes de discutirmos essa afirmação, procuraremos entender o que o autor entender por "autonomia":

Embora o campo literário possua claramente sua própria especificidade, seus valores, sua organização, seus objetos de debate e seus agentes de consagração. muitas das preocupações, tensões e estruturas do campo literário nos anos 30 são inseparáveis daqueles que pertencem a um campo intelectual mais amplo e do sistema social de que faz parte.( Johson, 1995, p.166)

Autonomia significa apenas que o campo literário conquistou uma lógica própria de funcionamento, e que não responde de forma subordinada a outros campos como o político, o econômico, ainda que interaja com estes. Até então o discurso literário não possuia esse espaço de constituição tão independente, segundo Randal Johnson.

Aqui voltamos ao início para prosseguir. Lembremos que Lafetá caracterizou a divisão modernista entre a conquista estética e a conquista ideológica. Tal divisão encontra respaldo no grande intéprete do modernismo, Antonio Candido. Randal Johnson traz outros elementos para reforçar essa leitura. Além das questões trabalhadas acima, Johnson lembra que uma das coisas que estava em jogo na disputa entre os modernismos era a legitimidade da crítica em definir a prática literária: "Nos anos 30, o debate literário concentrou-se em torno 
de dois grande tópicos inter-relacionados: o estatuto do Modernismo dentro do cânon literário nacional e a legítima definição da prática literária. (p.175)

O segundo ponto é o que nos interessa. Os espaços políticos que eram ocupados, as revistas publicadas, as cartas trocadas, as instituições que eram construídas tudo isso caminhava em um sentido que era político, sem dúvida, mas ocultava uma batalha pela legitimidade do fazer crítico e do fazer literário. Hoje é fácil apontar os vencedores, mas a dualidade de um Mário de Andrade, que mais do que qualquer outro escritor do período, encarou (e encarnou) as contradições trazidas por essa luta, mostra que essa disputa não foi pacífica, a ponto de o escritor paulista descartar o primeiro tempo modernista.

Aliás, foi sobre contradições que construiu a base que serviu à poesia dos anos 70 . A gradual conquista da autonomia do campo literário coincidiu com um aumento gradual da repressão no campo político, culminando no golpe de 64. O paradoxo se estende ao longo do período ditatorial, quiçá até os dias de hoje, visível na tensa relação entre liberdade e repressão, entre fala e escrita, entre expressão e construção, no "binômio 'milagre econômico/ fechamento político', que condensa a fórmula falsamente paradoxal da modernização conservador" (Bosi, p.161)

Por todos esses motivos, Johnson defende que há, nesse período, um campo literário autônomo. Tal afirmação poderia ser feita por Lafetá, Candido e tantos outros autores que se debruçaram sobre o modernismo. Um exame mais detido de alguns pontos pode nos ajudar a uma compreensão das diferenças entre o modernismo e os anos 70

\subsection{Uma preparação para os 70}

Nossa intenção é tão somente apontar alguns aspectos do campo autônomo dos anos 30, preparando o terreno para a comparação com os anos 70. Dentre os pontos que levantamos acima, tomaremos quatro: a participação dos escritores em debates outros que não o literário; o mercado editorial; a institucionalização da crítica literária; o binômio projeto literário/projeto de nação.

O primeiro ponto a ser examinado é a participação dos escritores em outros debates que não literários. É uma longa tradição da literatura brasileira, e que se repetiu até, pelo 
menos, o concretismo ${ }^{12}$. Existem ao menos duas leituras possíves, e complementares, sobre essa relação. A primeira é explicitada por Antonio Candido: "Diferentemente do que sucede em outros países, a literatura tem sido aqui, mais do que a filosofia e as ciências humanas, o fenômeno central da vida do espírito.” (Candido, 2000 p.119); outro ponto é o que colocamos acima, a luta pela legitimidade da prática literária. A combinação dessas duas possibilidades explicaria o porquê da literatura ter perdido espaço no campo das discussões sociais.

Em campos literários autônomos a literatura deixa de ser o centro de discussões sóciopolíticas e passa a ser o ponto de partida dessas discussões. Dito de outro modo, o espaço antes ocupado pela literatura, passa a ser ocupado pela crítica literária. Certamente há algo de peculiar no caso brasileiro, por nossa literatura ter um caráter participativo, mas isso também se dava por uma ausência de formação mais sólida em outras áreas. Um problema que começou a ser corrigido no romantismo e teve sua solução encaminhada no modernismo, não apenas pela excelente geração de ensaístas que se formou nesse período, mas pelo nascimento das primeiras universidades brasileiras na década de 30 .

É possível, ainda, vislumbrar uma luta, no campo, pela legitimidade. Embora seja comum que disputas desse tipo ocorram no ambiente acadêmico, podemos supor, com base nos campos literários contemporâneos, que uma vez autônomo, não é mais necessário haver disputas no campo para que determinado linha seja legitimada. O que há são disputas críticas, ainda assim amenas, raramente são disputas públicas e declaradas. Criam-se nichos de pesquisas que abrigam as orientações mais diversas, mas nunca entram em conflito direto.

Além disso, parece haver, como lembra Johson, algumas pressões externas ao campo literário brasileiro. Um exemplo mais claro é o abandono de princípios estéticos dos anos 20 em prol de uma maturidade ideológica. Essa busca é colocada de fora para dentro, por questões provenientes do campo político.

Ainda sobre as pressões externas, podemos pensar no binômio projeto literário/projeto nacional. É uma marca característica da literatura brasileira. Nossos grandes escritores carregavam além de grandes obras, grandes ideias para o país. Exige-se da literatura, até os dias de hoje, que ela cumpra esse papel.

Esse movimento era necessário, pois até os anos de 1930 não havia, de fato, nenhum aparelho que remontasse à ideia de Estado em nosso país. Mesmo com os avanços

\footnotetext{
${ }^{12}$ Uma pesquisa interessantíssima seria a relação entre estadistas e movimentos literários: José Bonifácio de Andrade, depois Joaquim Nabuco e os românticos, Vargas e os modernistas, JK e os concretistas.
} 
conseguidos pelo governo Vargas na tentativa de institucionalizar desburocratizando, não livra o país do clientelismo. JK, outro estadista que se empenhou na construção de um aparelho estatal, pouco conseguiu avançar. Isso não significa que hoje temos um Estado sem clientelismo, no qual a mistura entre público e privado não mais existe. Sabemos que é exatamente o contrário. Contudo, o aparelho estatal, depois de Vargas, JK e da ditadura está formado e consolidado. É a chamada modernização conservadora. Ou seja, o Brasil adota algumas estruturas do centro, mas sem se livrar de práticas que, em princípio, seriam contrárias a essa estrutura.

No caso da literatura, ainda que tenha sido uma modernização capenga, conquistada a modernização, não há mais o porquê de aliar um projeto literário a um projeto de nação; a nação está aí, o que se pode fazer é reformá-la. Além disso, como já apontamos, o campo autônomo pode abrir mão de discussões extra-literárias, o que não significa que a literatura passe a ser tão simplesmente um jogo de palavras, uma celebração do "eu", entre outras críticas e recriminações recorrentes. Significa que os temas a serem trabalhadas pelos escritores passa a ser definido segundo as próprias necessidades do campo.

Nesse sentido, temos ao menos dois grandes agentes "definidores de necessidade" no campo literário: o mercado editorial e a crítica literária. Debruçando-nos sobre esses dois agentes, podemos reforçar nossa tese de que o campo literário se modifica dos anos 30 para os anos 70 .

O mercado editorial modernista foi marcado pela presença quase opressiva da editora José Olympio. Excessão feita a Érico Veríssimo, nenhum dos grandes romancistas daquela geração, hoje canônicos, deixou de ser publicado por esta editora. É bem verdade que temos outras grandes editoras no período, como a Globo, a Aril e a Schmidt. Mas o domínio de uma editora apenas, embora tenha aumentado o volume de circulação de livros nacionais, ainda é nocivo ao sistema, pois há pouca abertura para a circulação de escritores. A liberdade é apenas aparente, pois a editora passa a ser, nas palavras de Johnson, "a condição sine qua non para a consagração."

Além disso, ainda de acordo com Johnson, a crise de 29 trouxe como uma dos consequências uma diminuição da importação de livros, o que pode explicar em parte o aumento do consumo de autores brasileiros. Não poderíamos explicar, portanto, o aumento na circulação da literatura brasileira apenas pelo surgimento de grandes editoras.

De qualquer modo, em comparação com o que ocorre nos anos seguintes, o mercado brasileiro ainda é incipiente. Desenvolveremos essa comparação mais adiante, mas apenas 
para reforçar nosso ponto de vista, o que ocorre nos anos 70, influenciado pelos planos de promoção do livro do governo militar, é um aumento incomparavelmente mais amplo. Merece destaque, adiantando um pouco da discussão que desenvolvermos, a criação de um mercado das editoras universitárias; até mesmo nos dias atuais elas são responsáveis por escoar boa parte da produção acadêmica, é possível imaginar a importância delas nos anos 70 .

Por fim, outro agente que ganha destaque a partir dos anos 30 é o crítico literário. $\mathrm{O}$ ataque feroz por parte de Afrânio Coutinho contra os críticos de rodapé, como eram chamados os críticos de jornais, é citado como exemplo por Johnson. A passagem de uma geração de críticos de jornal para uma crítica universitária, porém, é lenta. O debate citado, por exemplo, ocorre apenas no início da década de 50.

No caso da poesia marginal, essa mudança começa a mostrar seus primeiro sintomas para o campo. Alguns poetas começam a fazer o papel de agitador cultural, são aqueles que, como Cacaso, exercem mais de uma função no campo, transitando entre as diversas esferas, e algumas vezes entre diversos campos simbólicos, e ajudando outros a transitarem entre essas esferas do campo. A função não é nova, Mário poderia ser considerado um agitador cultural, mas nos anos 70 os agentes assumem um papel no mercado, além do campo simbólico. Por isso o professor universitário, que é poeta, jornalista e letrista acaba ganhando importância ${ }^{13}$ nesse período.

Devemos lembrar ainda que dois elementos dos mais marcantes para que a crítica praticada na academia ganhasse corpo, ocorrem apenas em fins da década de 60, início de 70: as agências de fomento e os cursos de pós-graduação. O primeiro significa que a crítica passa a ser um modo de ganhar a vida; há um mercado de trabalho que começa a ser desenhado. $\mathrm{O}$ segundo, para utilizar uma leitura que Candido aplica ao campo literário, os nossos modelos críticos passam a ser os modelos internos, isso é ainda mais curioso pelo fato de nossa primeira geração de críticos ter como objeto, orientados por Antonio Candido ${ }^{14}$, o modernismo. Portanto, a consolidação das instituições necessárias, da materialidade necessária para a prática de uma crítica literária acadêmica, ocorre nos anos 70.

\footnotetext{
${ }^{13}$ Curiosamente, essa figura do professor/crítico/editor/jornalista perdeu a função de agitador cultural, por consequiência perdeu a importância e se tornou quase um clichê no campo literário.

${ }^{14}$ Comparar os papéis que Candido e Mário exercem na constituição, respectivamente, de uma crítica literária nacional e de uma literatura nacional é um trabalho ainda por fazer.
} 
Pelo que tratamos acima é difícil sustentar que o campo literário brasileiro não se modifica nos anos 70. Vimos que muitas das instituições necessárias e que tiveram papel importante no campo literário brasileiro, se fortalecem nesse período. A força dos agentes como definidores do papel da literatura é um exemplo. Para falar com os conceitos de Candido, nossa literatura adquire maior maturidade nessa época.

Esse processo é compreensível: como seria possível uma literatura completamente madura se o próprio aparato do Estado ainda restava por ser construído? É certo que o modernismo de 30 deu grande passo na busca pela maturidade literária brasileira, buscando construir até mesmo as instituições necessárias para o funcionamento da literatura. Poderíamos dizer, aliás, que o processo de institucionalização da literatura brasileira, com a sua consequente autonomia, caminha lado a lado com o processo de institucionalização do modernismo, sendo o ponto de chegada as comemorações oficiais dos cinquenta anos da Semana de Arte Moderna de 22.

\section{Questões do campo literário dos anos 70}

Encontramos, nos anos 70, panorama bastante distinto daquele dos anos 20. As faculdades de Letras já estão consolidadas, vemos surgir nossos primeiros programas de pósgraduação em literatura, o próprio modernismo já se institucionalizou, como deixam claras as comemorações dos 50 anos do movimento, realizadas pelo governo militar.

A geração de escritores dos anos de 1970 foi a primeira a ter integrantes oriundos dos bancos das faculdades de Letras, tanto discentes quanto docentes. Soma-se a isso o fato do campo literário brasileiro estar em completo funcionamento com cursos de pós-gradução espalhados pelo país, instituições de fomento, publicações acadêmicas, polêmicas teóricas.

Todas essas mudanças não passaram em branco na escrita da geração da década de 70. Entender esse período é buscar entender também o que houve nas relações com a arte, o que houve nos processos de circulação e recepção das obras. Para tanto, é preciso um breve panorama cultural do período.

\subsection{Um breve panorama do período}


Ao traçar um perfil cultural dos anos 70, não procuraremos esgotar as leituras possíves, nem mesmo apontá-las todas. Gostariamos tão somente de indicar, dentre várias, vertentes que dominaram as artes nesse período e possuem, como tentaremos mostrar, relação direta com a poesia marginal: os questionamentos sobre a relação entre obra e público ou sobre o própio estatuto da arte ou ainda sobre a questão da representação toma conta de boa parte da crítica cultural, e da própria produção cultural a partir dos anos 50.

Nesse processo, podemos dizer que as artes plásticas tiveram papel de destaque, mas as outras artes, com exceção da literatura que comentaremos mais a frente, acabam por seguir caminho semelhante. Artistas como Duchamp, Magritte, Man Ray, Polock, Warhol e Helio Oiticica e Ligia Clark ${ }^{15}$ no Brasil mudaram o panorama das artes, a maneira como a arte se relaciona com a própria arte. Os redy-made de Duchamp fizeram com que a questão do que é uma obra de arte fosse levada ao limite; Magritte questionou a possibilidade de representação, Polock aliou o corpo e a pintura, Warhol criou, com sua obra, a figura da celebridade; no Brasil nossos grandes representantes foram Ligia Clark e Helio Oiticica, que imprimiram uma relação entre sua obra e o corpo, mudando também a maneira com que o público se relaciona com a obra de arte.

As questões artísticas que rondavam o campo cultural, contudo, carregadas desde os anos 20, passando pelos anos 50 e explodindo nos anos 70, eram recebidas por um ambiente político fechado, sendo ressignificadas. Falar sobre a exposição do artista e sua relação com o corpo é algo que ocorria desde Polock, passando por Warhol. Clark e Oiticica carregam essa relação com a repressão do governo militar, a qual passava diretamente por um controle sobre o corpo, não apenas com a tortura, mas o combate a manifestações e o direito de ir e vir.

Algo semelhante acontece na música. Temos a histeria dos Beatles se estendendo para o então nascente Rock n’ Roll, no Brasil a histeria dos festivais. Contudo, o uso de guitarras pelos tropicalistas gerou uma polêmica quanto ao "imperialismo" dos tropicalistas. A relação entre artista e público também aparece na múica. São questionadas, por exemplo, as relações entre os artistas e o povo, o alcance real dessa relação. Sobre o show Opinião de Nara, João do Vale e Zé Kéti, Heloísa Buarque faz a seguinte leitura:

\footnotetext{
${ }^{15}$ Nossa intenção não é esgotar as tendências artísticas entre os anos 20 e 70, mas apontar caminhos que influenciaram artistas brasileiros. Ao apontarmos Oiticica e Clark como representantes dos artistas brasileiros tampouco quisemos esgotar o campo artístico brasileiro. Apenas indicar dois representantes bastante importantes dos anos 70 .
} 
Impossibilitado de acontecer politicamente, o contato entre artista de classe média/povo passa a realizar-se em espetáculo. Mas essa representação - que é a mesma representação do lugar do intelectual ao lado do povo- já começa a ser questionada e passa a ser vista como incerta, como incerto era o momento (p.34)

A relação entre público e obra também aparece como uma questão no teatro. Cacaso, em texto para a Novos Estudos da Cebrap, discute o papel do teatro no ambiente cultura brasileiro. O texto apresenta interrogações bastante adequadas, destacamos uma, que nos serve de exemplo do que queremos mostrar: "A necessidade e a urgência de se criar relações autênticas com o público estão na base das principais tendências do Teatro moderno.” (p.266)

Roberto Schwarz, em texto hoje clássico, discorre sobre questões do campo cultural entre 1964 e 1969. Ele ressalta o parodoxo que envolve as condições de recepção e circulação da cultura ou, para falar com o próprio crítico: "Em seu conjunto, o movimento cultural destes anos é uma espécie de floração tardia, o fruto de dois decênios de democratização, que veio amadurecer agora, em plena ditadura, quando as sua condições sociais já não existem”.

Nesses retratos, muitos deles realizados no calor da hora, o que se percebe do Brasil é que viviámos em um paradoxo. Se há as condições materiais para que essa cultura amadurecesse, as condições sociais não existem. Essa aparente contradição é que dá a ressignificação, da qual falamos acima, para as relações do artista com o público e das relações do artista com a própria arte. Era preciso pensá-las considerando a falta de liberdade presente em nosso país. Há uma implicação do corpo na arte, de forma mais clara nas artes plásticas e na música, mas também na literatura através do desbunde. Aliás, a luta armada e o desbunde parecem ser duas faces da mesma moeda, pois ambas são maneiras de trazer o campo de batalha para o corpo, já completamente dominado pela ditadura. O habeas corpus havia sumido não só do vocabulário jurídico, mas do dia-a-dia da população.

Há aquilo que Viviana Bosi chama de "desintegração pessoal”:

A rejeição das explicações globais, totais, da realidade conduziu a uma fragmentação do discurso que o tornava solipsista e acidental (como vemos nos últimos poemas de Torquato Neto ou certos poemas de Ana Cristina Cesar). A ironia agressiva é tamanha que ela se prende a concepção de forma literária, produzindo um material bruto que se quer circunstancial, rebelde a toda mediação reflexiva, até quase se reduzir ao pré-estético. (Bosi, p.163,164)

Essa "desintegração pessoal", somada ao que Bosi chama de "pré-estético" nos leva a uma dificuldade de operar em um nível simbólico. Isto é uma característica marcante do 
período, que pode ser relacionado ao modus operandi da própria ditadura; como dissemos, a ditadura opera sua repressão sobre os corpos, não de forma simbólica como ocorre em um regime democrático.

Ainda com Viviana Bosi, retomando uma citação de Octavio Paz:

É por isso que, como lembra Octavio Paz, a geração dos anos 70 não era politicamente engajada, com que isso supõe de fé no porvir, o qual podemos compreender em um sentido marxista ( o sacríficio de sua vida pela revoulução), capitalista (a economia e a disciplina burguesas) ou ainda religioso (a fé nos valores eternos que sustentam a existência): seus membros se concentram no experiência presente. $\mathrm{O}$ poeta mexicano os chama não mais de "revolucionários", mas "rebeldes": "a rebelião da juventude é de natureza corporal e erótica, precisamente porque ela exalta o presente, o aqui e o agora", assim com o coletivo e aspecto festivo da vida, substituindo o paradigma do futuro pelo de presente. (Bosi, p. 162)

Por outro lado, o questionamento do estatuto da obra de arte, uma consequência do desbunde, encontrou um espaço nas disputas que já se desenhavam no campo cultural brasileiro. Nesse ponto, diferentemente do que ocorreu com as questões discutidas anteriormente, a literatura saiu na frente. A divisão entre vanguarda e engajamento é o pano de fundo do surgimento da poesia marginal.

Essa discussão, aliás, nos parece ser uma peculiaridade da literatura brasileira e envolve a relação arte/vida que discutimos no capítulo 1: a literatura deve buscar a comunicabilidade ou o hermetismo? Deve ser de fácil acesso ao leitor ou deve exigir a maturação da leitura? Essas oposições, no entanto, não se consolidam como verdadeiras. E a poesia dos anos 70 terá atuação importante para superar essa dicotomia.

\subsection{Os poetas e suas vidas}

Eventos ou obras que marcam o início ou o fim de um movimento cultural (ou de uma geração ou de um período) são elementos entre os mais importantes para a canonização. Tão importante quanto controverso, dada a impossibilidade de marcar de forma precisa quando um mudança no campo acontece. Controverso pois sempre haverá quem discorde da escolha de determinada obra ou envento como determinante para os caminhos daquela geração. Inevitável, contudo, daremos nossa contribuição para o processo de canonização da poesia marginal. 
Reforçamos uma data apontada por Heloisa Buarque ${ }^{16}$ como importante para o início dessa geração: 1972, com as "publicações" de O preço da passagem ${ }^{17}$, de autoria de Chacal, e Me segura que eu vou dar um troço, de Waly Salomão. Embora sejam normalmente colocados como situados em posições distintas, Chacal ao lado dos marginais, Waly ao lado dos tropicalistas, esses dois livros inauguram um novo tipo de procedimento estético na literatura brasileira; Chacal por uma estética peculiar do texto e da própria materialidade do livro, apresentando certo diálogo com a tradição brasileira; Waly pelo acúmulo de enunciações, situações enunciativas e gêneros textuais, bem definidos por Antonio Candido:

Nele se cruzam o protesto, o desacato, o testemunho, o desabafo, o relato, tudo numa linguagem baseada geralmente na associação livre e na enunciação caótica, formada de frases coloquiais, gíria 'hippie', obscenidades, períodos truncados, elipses violentas, transições abruptas, resultando um movimento bastante vivo cuja matéria é a experiência pessoal do autor. (Candido, 1972)

Ambos livros são marcantes e tiveram certa repercussão: o de Chacal como marca de uma poesia que começava a surgir no Rio de Janeiro, circulando de mão em mão, sendo vendida pelos próprios escritores; o de Waly como oposição a essa poesia marginal, vinculada aos tropicalistas, mas que trará um processo tão radical de composição que não será repetido na íntegra, e ainda assim aparecerá como influência em outros escritores.

Estamos diante, portanto, de dois processos distintos que juntos aparecerão no que há de melhor na produção poética dos anos 70: a estética que reverbera a tradição literária brasileira, fortemente fincada na coloquialidade; o processo de composição por acúmulos, deslocamentos e movimentos do enunciado, das enunciações e das situações de enunciação. Vemos isso em escritores com Ana Cristina César, como seus falsos diários, falsas cartas, em Francisco Alvim, o poeta dos outros, aquele que cede a voz e no próprio Cacaso, o poeta da escrita em suspensão, isso sem falar no próprio Waly, em Torquato, Guilherme Mandaro, Nicolas Behr e outros escritores que deixaram obras ainda por serem devidamente estudadas.

Não deixa de ser curioso, embora possa ser apenas uma coincidência, que o ano de 1972 representa também os 50 anos da Semana e que os modernistas de 22 estejam tão

\footnotetext{
${ }^{16}$ Hollanda, Heloisa Buarque. "Poesia Marginal" do site http://www.heloisabuarquedehollanda.com.br/?p=559 acessado em 13 de novembro de 2009. Ela contudo indica o livro de 1971 de Chacal como um data histórica importante.

${ }^{17}$ Em 1971 Chacal publica Muito prazer, Ricardo, mas com a circulação de apenas 100 cópias, a repercussão é inexistente.
} 
presentes nos diálogos que essa geração estabelece. Coincidência ou não, os modernistas explicam algumas coisas, como viemos tentando demonstrar, mas não explicam todas. É preciso entender o que há nesse período que eclode de maneira tão brusca ${ }^{18}$.

Fizemos acima um breve levantamento das característica do período cultural, assim como de alguns elementos do campo que consideramos importantes nos anos 70. Juntando essas duas leituras pensamos que será possível abrir algumas portas na compreensão da poética marginal como um todo, sem perder o foco em Cacaso.

\subsection{O espaço discursivo da literatura}

Talvez a mudança mais significativa dos anos 60 para os anos 70 seja o espaço discursivo da literatura. A música popular já era a porta-voz cultural, a literatura tinha deixado de ser o espaço privilegiado de reflexões culturais, políticas e sociais. Certo que era um reflexo do campo literário autônomo, conquista dos anos 40, o que não diminui os problemas que enfrentaram os escritores. A geração dos anos 70 era, portanto, a primeira geração literária a encontrar essa espécie de terra discursiva devastada para trabalhar sua escrita.

Era necessário aos escritores, pensamos sobretudo nos poetas, reconquistar algo desse espaço discursivo perdido, sem entrar em embate com o gênero canção, que pertencia a um campo distinto. Uma das formas encontradas foi mudar o processo de circulação das obras. Tirá-las das livrarias era trazê-las próximas ao público. Essa era uma opção não apenas porque o mercado editorial estava fechado à poesia ${ }^{19}$, mas porque era preciso fazer circular a poesia. Prova disso é o Expoesia, são os happenings seguidos de lançamentos de livros e, é claro, as edições descuidadas desses escritores; postos em conjunto, ajudam a entender que o

\footnotetext{
${ }^{18}$ O impacto da poesia marginal é tão intenso que já em 1973 ela aparece na I Expoesia da PUC/RJ.

${ }^{19}$ Essa afirmação sempre nos pareceu uma explicação fácil para um fenômeno mais complexo. Infelizmente não poderemos nos aprofundar nessa discussão. De qualquer modo, se o mercado estava fechado à poesia, fica difícil explicar porque todos eles foram editados pela Brasiliense logo no início dos anos 80 e estão sendo reeditados desde os anos 90 por grandes editoras
} 
leitor passava a ganhar importância no processo de escrita, uma importância também material.

A mudança no mercado editorial é mais um elemento relevante. O poetas marginais estão fora do campo quando participam como poetas, mas estão no centro quando participam como críticos. Essa contradição, somada às difíceis condiçoes de vida e difíceis condições de circulação da arte, ambas causadas pela repressão do regime ditadorial dos anos 70, estabelece relação com a tensa abordagem da escrita realizada pelos poetas marginais. Tal posição paradoxal, centro e margem ao mesmo tempo, só é possível pois temos um mercado editorial universitário já consolidado. Ele consome a crítica produzida pelos professores, que pela primeira vez circula em livros lançados pelas editoras, ou que circulam nos jornais, como consome também a poesia que circula de mão em mão nos espaços culturais típicos da juventude universtária como teatro, cinema e na própria universidade.

Outro ponto foi tornar a poesia mais comunicável ${ }^{20}$. Essa comunicabilidade passava pela coloquialidade, passava por uma busca pela oralidade. Não negamos o embate com a poesia hermética, certamente era um elemento no horizonte dos poetas; não negamos o diálogo com os modernistas, algo afirmado e reafirmado por boa parte da geração dos anos 70. Apenas acrescentamos uma variável a essa equação, uma variável que nos parece importante aliás. Afinal, uma das "desvantagens" da poesia em relação a música popular é que esta tem um consumo mais fácil e imediato do que aquela. Buscar um texto mais comunicável, portanto, não significa apenas rejeitar a poesia considerada hermética das vanguardas, mas significa também buscar o acesso de um público leitor. Ana Cristina, em depoimento a Messeder Pereira, dá o tom dessa busca:

Me lembro de uma frase típica do Cacaso (...) (ele) era o 'bom leitor', o 'classificador' e, uma vez, eu li (pra ele) um poema meu que eu tinha adorado fazer (...) e o Cacaso olhou com olho comprido (...) leu esse poema e disse assim: "É muito bonito, mas não se entende (...) o leitor está excluído". (...) Aí eu mostrei também o meu livro pro Cacaso e (ele) imediatamente... quer dizer, aqueles 'diários' da antologia eram dois textos de um livro de cinqüenta poemas... (e ele disse): "Legal, mas o melhor são os diários, porque se entende.... São de comunicação fácil, falam do cotidiano. (CESAR apud PEREIRA, 1981, p.229).

\footnotetext{
20 Viviana Bosi faz uma ressalva importante: "Em nossa opinião, a percepção de exílio social, da incomunicabilidade alimenta numerosos escritos desse período (no sentido amplo), seja em Ana Cristina Cesar, Torquato Neto, Cacaso, Francisco Alvim, Armando Freitas Filho, Sebastião Uchôa Leite.”(p.165) Esse parodoxo, mais um dentre tantos do período, aparece na construção da poesia de Cacaso.
} 
Cabe lembrar que Cacaso era o teórico da geração; como a própria Ana Cristina aponta, ele era o classificador. Sua opinião não apenas tinha peso entre os escritores, mas podemos supor que é reflexo de uma maneira de enxergar a poesia de toda a geração.

Essa busca pelo espaço discursivo vai, inclusive, fazer com que diversos poetas trabalhem como letristas. Cacaso é um exemplo, como exploramos no capítulo 1, mas há ainda escritores como Chacal, Charles, Ronaldo Bastos, Capinam, Bernardo Vilhena, para ficar com alguns exemplos apenas. Não podemos dizer que isso é uma espécie de "se não pode vencê-los, junte-se a eles", pois eles continuam a escrever poesia. É apenas a busca por ampliar o alcance dos textos, ainda que a materialidade destes seja diferente.

Não era, porém, apenas a música popular que pressionava a literatura na busca por maior aproximação com o público. Como mostramos em nosso breve panorama, outras artes colocavam como um problema de criação a circulação das obras. Os marginais, além de buscarem o corpo a corpo, tirando o livro da livraria, questionando mesmo o conceito de livro, além de se voltarem a comunicabilidade pela oralidade, mudaram a temática corrente da poesia e começaram a tratar do cotidiano. Mais uma vez, há a presença dos modernistas, mas mais uma vez ela não explica sozinha porque esse cotidiano dos anos 70 é muitas vezes dilacerado, recortado, rarefeito. É um cotidiano no qual, apesar da presença do "eu", se sobrepõe o valor coletivo.

Ainda pelo mesmo prisma do espaço discursivo, consideramos ser possível explorar o porque desse valor coletivo da poesia marginal. Essa geração dos anos 70 ficou marcada por grupos e coleções como Frenesi, Nuvem Cigana, Vida de Artista, fato que também é inédito em nossa tradição literária. Contudo a leitura corrente parece confundir atuação coletiva com criação coletiva.

Há explicações, ao que nos parece, bastante plausíveis para explicar esse fenômeno. O primeiro elemento é que ao se afastarem do mercado editorial, em um primeiro momento por falta de opção, depois pela liberdade que o afastamento proporcionava, arcar com os custos era mais fácil quando estes eram divididos. Além disso, há o momento histórico, de forte repressão. Em momentos como esse, juntar as vozes, ainda que não dissessem todas as mesmas coisas, era melhor do que falar sozinho. Não que a atuação coletiva fosse em si uma forma de resistência, mas atuar coletivamente dava amplitude maior àqueles que queriam se fazer ouvir sem se deixar abafar pelo silêncio imposto. Cacaso parece dar conta desses dois aspectos, a partir de uma ideia que se transformou em conceito: o poemão. 
Embora nunca tenha sido formulado por Cacaso como um conceito crítico ${ }^{21}$, a expressão foi retomada como se o fosse em textos diversos de críticos e leitores da poesia marginal. Foi também adotado como uma leitura da geração dos anos 70 pelos próprios escritores. O parodoxo é que a ideia foi poucas vezes aproveitada na leitura dos poemas e foi tomada de forma literal, como se fosse possível ver a poesia praticada nos anos 70 como uma só, essa leitura é a fonte provável do método coletivo de se ler a poesia marginal. Outro tipo de abordagem vê no poemão uma forma de resistência. Parece-nos, pensando ainda em uma outra leitura, que esse é um conceito que, nas palavras de Iza Quelhas "sintetiza o que o escritor pensa sobre a relação do intelectual com a cultura e a política”.

Poemão, então, é um modus operandi da escrita, é a forma de concretizar a historicidade tanto da produção quanto da leitura. Daí a dificuldade em transformar a ideia em conceito crítico; o poemão é uma prática que pode ser dissecada não na tentativa de ler a poesia dos anos 70 como um conjunto, mas no modo como cultura, política e poética se cruzam, de diferentes maneiras em diferentes escritores ${ }^{22}$. Desse modo, ligados uns aos outros pela história, questão acentuada pela forte repressão do período, nada poderia ser feito a não ser escrever o mesmo e gigantesco poema. O poemão é a subjetividade, um lugar no discurso que pode ser ocupado por diversas vozes, que não é fixo. Cabe uma citação de Cacaso:

Essa poesia de agora principia tendo interesse pelos seus assuntos, pleo material de conhecimentos que expõe, processa e analisa, e que é, a um só tempo, comum ao indivíduo e a um grupo social maior. Existe uma continuidade profunda de experiência entre os poetas, que de alguma forma se manifestará na produção de cada um, com os poemas se interpenetrando, se confundindo uns com os outros, como se fossem partes complementares de um mesmo poemão que todos, sem qualquer combinação prévia, estivessem compondo juntos. A poesia um pouco como sintoma (Brito, 1997, p.81-82).

A nosso ver, o grande problema com a afirmação de que existe um processo de escritura que pode ser lido em seu conjunto é que essa leitura levou a poesia marginal a ser abordada sempre em bloco, além de ignorar diferenças sensíveis entre seus representantes. Contudo, a essência do trecho de Cacaso corrobora a leitura que propomos do poemão: é uma

\footnotetext{
${ }^{21}$ Essa leitura peculiar da poesia marginal foi apenas uma observação, relatada por Heloisa Buarque, Cacaso nunca a sistematizou.

${ }^{22}$ Parece-nos que o poemão pode ser utilizado como conceito para boa parte da produção cultural do fim dos anos 60 e dos anos 70 .
} 
forma de materializar a continuidade profunda de experiência entre os poetas, experiência comum ao indivíduo e a um grupo social, ou seja, criar um espaço de subjetividade que permita a criação de um espaço discursivo coletivo ${ }^{23}$.

Partindo dessa proposta de leitura, podemos pensar o paradoxo da poesia do "eu", uma denominação comum para a poesia dos anos 70, e a atuação coletiva. Parece-nos outra formulação do binômio arte/vida. É Flora Süssekind que chama atenção para o fato de que o "eu" da poesia não é uma constituição do sujeito: "Este eu, no entanto, em que parece se centrar a produção poética dos anos 70, não é idêntico àquele dos depoimentos, biografias e memórias. Aliás, sequer presta reverência à memória(...)" (Sussekind, p. 115). Podemos notar que muito da discussão sobre a poesia do desbunde centrou-se no uso do verbo em primeira pessoa, como se fosse isso o bastante para a constituição do sujeito, como se na voz de um, não pudessem ecoar vozes de outro, como se os problemas do "eu", não fossem, por vez, problemas coletivos, principalmente pelo fato desse texto não ser uma poesia lírica confessional, ser um "eu" que não se afirma, não ser um "eu" expressivo. Viviana Bosi lê o fenômeno da seguinte maneira:

De fato, percebe-se uma desindividualização na recorrência dos temas mais ordinários do cotidiano e na reiteração das mesmas formas de construção. Paradoxalmente, aquele que foi o signo de um desvio em matéria de qualidade decorre, nos melhores poetas, de uma escolha consciente. (Bosi, p.165)

O famoso texto de Iumna Simon e Vinicius Dantas faz uma avaliação negativa desse aspecto e usa uma pequena antologia somente com poemas que utilizam o verbo em primeira pessoa. Selecionamos algumas para discutir:

meu amigo de infância continua emagrecendo

fala depressa

diz que a vida tá difícil

que mário continua exagerando

que ele vai à praia ali mesmo

enquanto a cerveja sobra no copo

alguma coisa sobra no papo

a noite apenas começa

Guilherme Mandaro

23 A percepção de que a função de um discurso é criar um espaço de subjetividade é semelhante ao que o teórico Henri Meschonnic chama de "poética do sujeito". Tal poética não pode existir sem um conjunto de política e ritmo. 
Há certa perversidade em dizer que o processo de "re-subjetivização faz coincidir o sujeito poético com o sujeito empírico" e embaixo de todos os poemas colocar o nome do autor. É bastante provável que esta tenha sido uma exigência da antologia concisa organizada pelos autores. Até mesmo porque a confusão entre poesia e vida que supostamente existe na poesia marginal é ideia que aparece também em Heloísa Buarque, embora com um valor mais positivo. De qualquer modo, nada vemos no poema que indique uma coincidência entre sujeito lírico e sujeito empírico. Ainda que pudéssemos provar que Mandaro conhece um Mário, em nada isso seria a definitiva evidência de que se trata de um poema em tom confessional.

Trazer elementos da conversa amena para a literatura, dando lhe um caráter (auto)biográfico é uma forma muito interessante de ficcionalizar o particular. Em um momento, que talvez só tenha se agravado nos dias atuais, quando não se tem mais controle sobre o próprio tempo, como consequência sobre o próprio corpo, trabalhar o cotidiano como uma ficção é necessário, pois não há mais espaços discursivos fixos. Acabaram-se os lastros do discurso, posto que aquilo que os sustentava, um sujeito com um corpo, já não tem mais controle sobre si mesmo.

Os melhores escritores dessa geração vão utilizar esse procedimento das maneiras mais diversas. Ana Cristina César talvez tenha sido o grande exemplo em seus jogos com situações de enunciação, espaços discursivos, nos quais o "eu" nunca se afirma, embora todas o enunciado seja justamente o contrário, como cartas e diários. Vejamos um exemplo da antologia de Simon e Dantas:

Noite de Natal.

Estou bonita que é um desperdício.

Não sinto nada

Não sinto nada, mamãe

Esqueci

Menti de dia

Antigamente eu sabia escrever

Hoje beijo os pacientes na entrada e na saída

com desvelo técnico.

Freud e eu brigamos muito.

Irene no céu desmente: deixou de

trepar aos 45 anos

Entretanto sou moça

estreando um bico fino que anda feio,

pisa mais que deve,

me leva indesejável pra perto das 
botas pretas

pudera

\section{Ana Cristina César}

À sombra do diário aparece: um registro de um dia, diálogos com a mãe, confissões cheias de culpa, rastros de certa raiva. O que fica, no entanto, é a ausência de qualquer informação pessoal. O sujeito não se constitui como tal, mesmo diante de uma situação enunciativa, no caso o diário, na qual a sua presença é a condição própria de existência do gênero. Esse tipo de processo, essa busca por um espaço discursivo próprio, vai levar a cabo a própria escrita.

A combinação dos diversos fatores que mecionamos é que resultará nessa escrita em extinção; ao rejeitar uma literatura que, na visão dos escritores marginais, não era acessível e buscar um contato com o público de uma forma que já estava sendo feita pela artes plásticas e pela música popular, ou seja, a maior proximidade, eles necessariamente terão de colocar o próprio corpo em jogo. É o que acontece, como também vimos, com Waly Salomão em $M e$ segura. Em diferentes graus, com diferentes implicações é o que acontece com Cacaso, Ana Cristina, Francisco Alvim, para ficar com nossos exemplos recorrentes.

Nem sempre essa será uma ferramenta que funcionará, e muitas vezes o poema será vazio. É o que podemos ver no seguinte poema, também retirado da antologia já citada:

troco agorinha se você topar uma epopéia em dez cantos por um canto pra dormir toda a semana de trabalho por um instante do caralho o que não sou mais agora pelo que nunca fui antes minhas descuidadas cinzas por seus pesados brilhantes Eudoro Augusto

O instante eternizado em um texto perde um pouco de sua magia. O deslocamento de situações enunciativas nem sempre criará espaços discursivos. Muitas vezes o texto se resume a um "gosto hedonista de se brincar com a própria sensibilidade. Esses problemas não diminuem, contudo, as conquistas dessa geração. Da maneira como vemos, houve um grande ganho para a literatura brasileira, pois a partir da conquista do "direito de errar" dos modernistas, os marginais puderam criar uma dicção própria.

Essa dicção absorveu muito do espírito da época, principalmente das condições de circulação e recepção da obra de arte. Fica a questão, contudo, de porque não ter havido 
continuidade desse movimento na literatura brasileira. A resposta talvez venha com uma breve comparação entre o campo literário modernista e o campo literário marginal.

\section{A interrupção de um movimento}

$\mathrm{Na}$ defesa de que há uma ruptura entre ideologia e política no movimento modernista, há também o raciocínio que na literatura de 22 o valor maior estava na atitude literária. Não que não houvesse grandes obras, muito pelo contrário. Reconheceu-se desde a primeira leitura a grandeza de um Serafim Ponte-Grande e de um Macunaíma. O que não havia era a consolidação dessas obras na sociedade brasileira, sua maturidade ainda não havia sido alcançada.

A poesia marginal também foi mais valorizada, ao menos no calor da hora, por suas atitudes literárias. Não que a poesia marginal não tenha apresentado, também, grandes obras. Podemos apontar Beijo na Boca, de Cacaso, e Passatempo, de Francisco Alvim como exemplos. Ela ainda alcançou a institucionalização em 30 anos, algum tempo antes do que os 50 que levaram os modernistas: já na década de 90 começaram as explorações acadêmicas e nos anos 2000 houve uma reedição de obras desses poetas em edições muito bem trabalhadas.

Para os marginais, no entanto, o período de maturidade não chegou. Não houve para eles uma "geração de 80", a qual pudesse consolidar os ganhos literários e transformá-los em ganhos políticos. Podemos esboçar diversas teorias, sendo a mais óbvia a morte de dois dos principais escritores, Cacaso e Ana Cristina César, antes que eles pudessem continuar sua obra. Podemos especular com a passagem de cima para baixo de um Estado Ditatorial para um Estado Democrático de Direito. Podemos ainda supor que a poesia marginal tenha estourado na canção pop dos anos 80, em bandas como Blitz, Kid Abelha, Paralamas do Sucesso e toda a geração do Circo Voador.

É bem provável que a explicação contemple um pouco de cada uma dessas possibilidades. O fato é que não houve um evento ou um movimento ou uma geração que fizesse pela poesia marginal o que a geração de $30 \mathrm{fez}$ pelos modernistas. Por isso o questionamento de Simon e Dantas sobre a validade de uma poesia que era valorizada por suas atitudes em determinado contexto, depois de uma mudança de contexto. A dificuldade em lidar com o legado marginal, que pode ser vista nas edições de luxo da coleção Às de 
Colete ou mesmo em uma tendência de criar hagiografias dos escritores falecidos como aponta Flora Sûssekind.

Ainda falta entender muito dos procedimentos da poesia marginal. Talvez Ana Cristina tenha sido a única a receber um tratamento mais cuidadoso, não sem cair, ainda citando Sûssekind, na hagiografia ao buscar nos textos da escritora explicações ou conexões com seu suicídio. No próximo capítulo procuraremos voltar aos textos de Cacaso, já de posse de todas essas informações e verificar de que modo a escrita é questionada em seus textos. 


\section{A especificidade: a escrita em suspensão}

\section{Para onde convergem nossas questões?}

Nos dois primeiros capítulos buscamos mostrar dois pontos que serão colocados lado a lado neste terceiro capítulo: a busca pela liberdade que guia as reflexões de Cacaso, com forte orientação em uma leitura bastante específica dos modernistas; as mudanças dentro do campo literário, além das óbvias mudanças sócio-econômicas no Brasil, que implicam diferenças no papel da literatura, assim como no modo com que ela é encarada pelos produtores e pelos consumidores. Trouxemos ainda a questão do estatuto da escrita entre os poetas marginais. Parece se tornar um ponto pacífico que essa produção poética não pode ser lida com o mesmo arsenal teórico utilizado para ler a produção modernista. Há, como defende Teresa Cabañas, "uma modificação da função poética moderna". Sugerimos, ao final do segundo capítulo, que um eixo de leitura para entender essa nova poética moderna seria entender o que ocorre com o processo de escrita.

Há uma busca por novos espaços de escrita, adquirindo valores diferentes para cada escritor, mas podemos dizer, correndo o sabido risco da generalização, que há um trabalho com a escrita que leva à sua suspensão, leva a quase uma espécie de não-obra. É uma consequência da maturidade de uma estética do desleixo, da maturidade do trabalho que se coloca entre a tradição literária, não apenas brasileira, e a tradição oral. Uma relação tensa que pode levar a uma poesia infrutífera, como de fato ocorre mesmo com Cacaso, ou pode trazer questões interessantes, com reflexos para a produção poética contemporânea. 
Infelizmente, não será possível trabalharmos esses desdobramentos, nem mesmo voltar com maior profundidade para produção marginal, restará a nós apontá-los, enquanto trabalhamos com a poética de Cacaso.

\section{Intelúdio teórico}

Cabe explicar a nossa escolha pela ideia de deslocamento da enunciação, conceito já utilizado nos dois primeiros capítulos, e não de intertexto. De início, talvez caiba explicar o que chamamos de deslocamento da enunciação, e o porquê deslocamento da enunciação e não do enunciado. A enunciação é o enunciado em ato. Aquela, diferente deste, não pode prescindir do contexto, entendido aqui não apenas como a situação na qual é pronunciado um enunciado, mas seu interlocutor, para ser entendida. Isso equivale a dizer que um enunciado contém ou está contido em virtualmente infinitas enunciações. Um exemplo seria a fórmula de rotina "Bom dia!", enunciado que, podendo ser proferido em contextos dos mais diversos, aos mais diversos interlocutores carrega como potencialidade diversas enunciações. Ainda como ponto de diferenciação, o enunciado não tem valor pragmático, que está todo nas enunciações porvir. Na definição de Ducrot e Todorov, enunciação é "um ato no decurso do qual as frases do enunciado se atualizam, assumidas por um emissor particular, em circunstâncias espaciais e temporais precisas.”(1973)

O deslocamento da enunciação é a significação, constituída pelos elementos pragmáticos, sintáticos, semânticos, trazida de uma situação enunciativa que dá à enunciação nova signifcação em outra situação enunciativa sem que a antiga se apague. Pelo contrário, para construir o processo de significação é necessário unir essas duas situações. Obviamente, isso depende muito do leitor. "Situação de enunciação" é bastante semelhante ao que Ducrot e Todorov chamam de "situação do discurso":

o conjunto das circunstâncias no meio das quais se desenrola um ato de comunicação (oral ou escrito). Deve-se entender por isto, ao mesmo tempo, o ambiente físico e social em que se realiza o ato, a imagem que dele tem os interlocutores, a identidade destes, a ideia que cada um tem do outro (incluindo a representação que cada um tem do que o outro pensa dele), os acontecimentos que precederam o ato de enunciação (sobretudo as relações que antes tiveram os interlocutores) e, sobretudo, as trocas de palavras em que se insere a enunciação em questão. 
Devemos entender, contudo, o modo como pensamos a intertextualidade a partir do conceito de deslocamento da enunciação. O problema se coloca quando o diálogo que o autor estabelece não é apenas com o enunciado, mas com uma situação enunciativa. Cacaso não está relacionando textos; ele parte de um contexto de fala, que não é definido, para chegar ao texto, por exemplo. Utiliza diálogos, provérbios e mesmo idéias que já foram integradas ao senso comum, como, no caso específico do livro que tomamos para a análise, o amor romântico. Ou seja, as situações enunciativas não são apenas textos definidos, mas ideias cristalizadas, são frames, scripts, esquemas ${ }^{24}$ clichês.

Nesse modo de ex-apropriação é fundamental ao conceito de intertexto é que não se leva em conta o contexto do enunciado com o qual se dialoga. Por exemplo, se retomo um texto de Chico Buarque, como veremos a frente, via de regra não se leva em conta a percepção que esse texto já havia causado, ele é lido em sobreposição ao texto e não no espaço de conflito entre o novo sentido que o trecho adquire e o sentido que ele já carregava. A intertextualidade, quando considera apenas o enunciado, não considera a dinâmica sempre presente na leitura, apenas a dinânica da escrita. Ou seja, o texto ao qual se faz referência é tomado apenas como um texto base, não como um diálogo ou uma maneira de criar novos sentidos para um enunciado antigo.

O deslocamento da enunciação é algo que está bastante presente no texto de Cacaso. É o modo que ele encontrar para estabelecer diálogos com outros formas de produção, textual ou não, e buscar a liberdade para e da escrita. Essa ferramenta, contudo, não é criação dos poetas marginais, já estava presente nos textos mais ricos da poesia modernista. A diferença é que os poetas dos anos 70 trabalharam no limite com esse instrumento poético, dando a ele uma feição distinta da que recebeu de poetas como Oswald e Bandeira.

Começamos a apontar essa diferença ao fim do primeiro capítulo, quando comparamos um poema de Cacaso e um poema de Bandeira. No texto do modernista havia a mediação, permitindo que se reconhecesse a origem de cada situação enunciativa, separando aquilo que seria a situação enunciativa original. Dessa maneira, cada conjunto de enunciações é colocado em separado, impedindo que se sobreponham, impedindo que ocorra o deslocamento da enunciação, já que ela sempre está devidamente localizada. O mesmo ocorre

\footnotetext{
${ }^{24}$ São todas categorias oriundas da linguística, da psicologia, das ciências cognitivas. Referem-se aos processos de construção do conhecimento, que remetem a um paradigma da experiência, ou seja, são estruturas de expectativa, modelos cognitivos, servindo como referência a um tipo de comportamento em determinada situação, ao que deve ser dito em determinado contexto.
} 
com Oswald. Com Cacaso e outros poetas dos anos 70, o processo de delocamento da enunciação é a essência do processo constitutor. É preciso deixar claro que, com isso, não pretendemos estabelecer uma comparação qualitativa, mas apenas mostrar diferenças; são momentos históricos distintos, que exigem uma postura distinta diante da escrita.

\section{Uma proposta de leitura}

Propomos como chave de leitura para a poética de Cacaso, o que chamamos de escrita rarefeita. Veremos que esse processo, que se constitui como uma aproximação do texto poético a partir do que classificamos como deslocamento da enunciação e de uma contínua contradição performativa, não está presente desde o início da produção poética do poeta mineiro. $\mathrm{O}$ deslocamento de situações enunciativas não é o mesmo tipo de intertextualidade sobre a qual fala Julia Kristeva e que parece ser o uso mais comum:

Tout texte se construit comme mosaïque de citations, tout texte est absorption et transformation d'un autre texte. A la place de la notion d'intersubjectivité s'installe celle d'intertextualité et le langage poétique se lit, au moins, comme double. (Kristeva, 1978, p. 438-65)

O intertexto cacasiano não é mera citação, não é simples referência, não é sobreposição de sentido. Envolve todas essas questões e, principalmente, o contexto do qual é retirado o enunciado e reververa na nova situação enunciativa em que é colocado. Não basta, portanto, percebermos que determinado poema faz referência a Jorge de Lima, mas é preciso voltar ao poema de Jorge de Lima, entendê-lo em seu contexto original, para depois voltar ao texto cacasiano e fazê-lo ressignificar. Propomos uma extensão do conceito de intertextualidade.

A mudança não é brusca, tampouco é gradual. É uma transmutação que aparece em diversas frentes, em níveis diversos, com profundidade diversa: a preocupação com a liberdade, que nunca deixa de aparecer, assume uma feição técnica no trato com a escrita e nas reflexões sobre ela na poesia; a mesma liberdade, na canção, é um flerte com as possibilidades do mercado; como professor universitário e ensaísta, o trânsito em diversas 
frentes, possível apenas pela posição central que ocupado pelo crítico, é que se torna liberdade. Tudo isso sob o forte regime militar, sob a repressão, sob o corpo dominado pela tortura.

Nessa complexa relação é que se constroem os temas cacasianos e sua apropriação tão particular das enunciações alheias ${ }^{25}$. Francisco Alvim era chamado por ele de "poeta dos outros", aquele que cedia a voz. Cacaso é o poeta afônico, tem a voz, mas uma voz rouca. É talvez aquele em quem a contradição toda do período explodiu, levando a um tipo de poema que se destaca pela instabilidade, por um livro que trabalha com um relaxo, mas possui características de um livro em sua acepção forte, pelo diálogo constante com a literatura brasileira e o jogo com enunciações típicas do dia-a-dia.

\subsection{Nem dono nem inquilino}

Como colocamos ao final do capítulo anterior, o ganho que a poesia marginal traz para a poesia é o de colocar o processo de escrita nas cordas. Cacaso foi o ponto de partida em nossa reflexão, sobretudo pelo que ocorre no livro Beijo na Boca, no qual, como pretendemos apontar, vemos a maturidade da escrita cacasiana.

A mudança teve início na leitura particular que nosso poeta faz do movimento modernista de 22 e do interesse que manifesta pelas questões relacionadas a liberdade de e para a escrita, questões discutidas no capítulo 1 . O processo é vagaroso, confundindo-se com a própria relação que o escritor mantém com a poesia. Em seu primeiro livro, A palavra cerzida, é constante a metáfora do fechamento. Frequentemente visto sob a ótica da influência, por haver um diálogo com outro poetas já consagrados naquele momento, como João Cabral, Drummond e Cecília Meireles, lido sob o viés da liberdade, em uma espécie de leitura de reconstrução de um percurso, outras questões interessantes aparecem:

\section{O Pássaro Incubado}

O pássaro preso na gaiola é um geógrafo quase alheio:

Prefere, do mundo que o cerca,

\footnotetext{
${ }^{25}$ Ana Maria Domingues, em artigo sobre a intertextualidade em Cacaso, chega a pontar uma auto-referência em diálogo entre dois poemas de Cacaso: "Fábula", do livro Palavra Cerzida e "Lar doce lar", do livro Na corda bamba.
} 

não as arestas:o meio
É isso que o diferencia
dos outros pássaros: ser duro.
Habita cada momento
que existe dentro do cubo.
Ao pássaro preso se nega
a condição acabado.
Não é um pássaro que voa:
é um pássaro incubado.
Falta a ele: não espaços
nem horizontes nem casas:
Sobra-lhe uma roupa enjeitada
que lhe decepa as asas.
O pássaro preso é um pássaro
recortado em seu domínio:
Não é dono de onde mora,
nem mora onde é inquilino.

Pouco podemos afirmar sobre o pássaro. Muitas das informações que nos são fornecidas o são por um viés negativo, sempre dizendo aquilo que ele não é. Contudo aquela que talvez seja a informação mais importante nos é dada no início: trata-se de um pássaro incubado. A palavra "incubar" recebe no dicionário Houaiss cinco definições: trazer, ter em estado latente (uma moléstia); preparar laboriosa e paulatinamente; planejar, arquitetar, elaborar; convencer-se intimamente; compenetrar-se, persuadir-se, além do sentido de chocar um ovo; mantê-lo em uma incubadora.

Pela redundância, já que todo pássaro deve ser incubado, e pela presença do artigo definido, que faz parecer tratar-se de um pássaro específico, descartamos as duas últimas definições. Restam-nos as três primeiras. Todas elas apontam para algo interno, algo que está dentro e manifesta-se no mesmo momento em que age. O pássaro incubado esconde algo, mas nunca nos é mostrado o que é esse algo, o que ele traz latente, o que planeja, o que prepara.

As imagens que o poema cria não se completam, criando uma figura desconjuntada. $\mathrm{O}$ título anuncia um pássaro incubado, afirmação que é reiterada pelo primeiro verso com o pássaro preso. Contudo, ele tem preferências, prefere o meio as arestas, como se fosse um geógrafo desatento, que nada tem a ver com o assunto. Essa construção paradoxal se repete 
na relação entre a terceira e a quarta estrofe: nesta anuncia-se o que lhe falta, mas é mostrado o que não falta e o que sobra, naquela há uma afirmação da condição de preso do pássaro. Essas duas informações, aliás, não se juntam para formar uma fotografia terminada, pelo contrário, elas se contrapõem: há espaço, horizonte, casa, mas o que lhe resta é uma roupa reprovada que lhe corta as asas. Ou seja, o pássaro dispõe de liberdade, mas não pode dela usufruir. Por outro lado, a estrofe anterior nega essa leitura, já que a condição de acabado não lhe é permitida, ele nem mesmo pode voar, está incubado. Não há, portanto, uma liberdade que é rejeitada. Essa impossibilidade de construir uma leitura definitiva do pássaro está sacramentada na última estrofe: o pássaro não é dono nem inquilino, mas habita. Não há espaço possível para ele.

A irregularidade do ritmo do poema também nos passa essa imagem. A métrica, apesar de apresentar um predomínio da redondilha maior, traz versos em sextilha, em redondilha menor e até em oitava. $\mathrm{O}$ mesmo ocorre com a acentuação. $\mathrm{O}$ poema tende a um ritmo ternário, mas muitas vezes apresenta um andamento binário ou mesmo quaternário. Vejamos:

$01 / 2 / 31 / 2 / 3 / 41 / 2$

O Pássaro preso na gaiola

$1 / 2 / 3 / 1 / 2 / 3 \quad 1 / 23 / 1 / 2$

É um geógrafo quase alheio:

$0 / 1 / 2 / 31 / 2 / 3 / 1 / 2$

Prefere, do mundo que o cerca,

$1 / 2 / 3 / 1 / 2 / 3 / 1 / 2$

Não as arestas o meio.

A estrofe inicia com uma espécie de anacruse, que se repete no início do terceiro verso. Vemos que a predominância é do ritmo ternário, mas todos os versos terminam em um ritmo binário. Aliás, todos os versos do poema terminam em um esquema de acentuação binário, ou seja, à tônica precede apenas uma sílaba, exceção feita ao primeiro verso da última estrofe, que termina com a palavra "pássaro". Contudo, a palavra pode ser pronunciada como "pásro" no contexto do verso: “o pássaro preso é um pássaro", pois o primeiro "pássaro",comprime a leitura do segundo "pássaro". Esse final, repetidamente marcado por uma sílaba forte e uma fraca, dá a impressão de um andamento regular, apesar de não existir um ritmo que se repete, ou mesmo uma métrica regular. O paradoxo na 
estrutura rítmico-métrica traz a mesma questão da aparente liberdade, representada pela métrica irregular, que não se consuma, já que o ritmo tende a regularidade.

Se somarmos a nossa leitura o título do livro "Palavra Cerzida" e a parte na qual o poema está inserido, "O lado de dentro", podemos propor uma aproximação entre a figura do pássaro e o próprio processo de escrita. "Cerzir", de acordo com o dicionário Calda Aulete, quer dizer, coser sem deixar vestígios, ou, em sentido figurado, unir, juntar. O título remete ao trabalho com a palavra, primeiro a palavra costurada sem deixar os vestígios dessa costura, a segunda a palavra unida. O lado de dentro da peça costurada traz justamente os vestígios dessa costura. Isso não significa que Cacaso quisesse expor o processo de construção, mas uma reflexão sobre ele.

O fechamento faz o papel de espaço de reflexão sobre a escrita. Essa figura do fechamento aparece em diversos outros poemas do livro. Em "Gameleira" temos estrofes como a que segue:

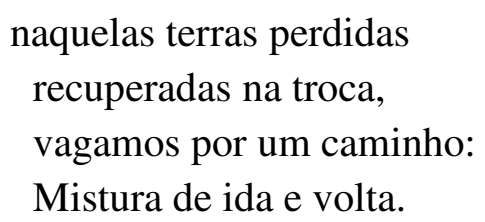

A indefinição entre ir e vir se repete por todo o poema. Cria a paradoxal sensação de um movimento sem o ato de se mover. A impotência diante do clima, diante da vida e da morte é a sina da Gameleira. É, também, a sina da própria escrita.

Nos poemas "O Arlequim" e "O samurai", a solidão e o olhar para dentro começa com a escolha das figuras que dão título ao poema, ambas representam personagens sempre caracterizados como solitários, presos por suas funções a uma vida sem as relações pessoais. A definição sobre eles também é ambígua: "O samurai:/Este grito calculado" e "O arlequim:/Não a morte servida em pedra,/ sua calada espessura/em tais retinas moldada:/Mas este nervo exposto, esta ausência/ritmada." No primeiro temos um grito, um ato de libertação, mas calculado; é um paradoxo, a liberdade que não se consuma. O segundo aponta um nervo exposto, a ausência ritmada, duas imagens não se complementam; o nervo exposto traz uma sensibilidade impossível de não se notar, enquanto que a ausência ritmada indica o contrário, algo difícil de perceber, novo paradoxo.

Ainda sobre os poemas como figuras de fechamento temos um que merece análise um pouco mais detida: 


\section{A OSTRA;}

A ostra medita em ares sem fala: Mistério de vida trancado na jaula.

Não há neste cofre um canto que embala:

É mudo o fio que tece na alma.

A ostra consome a própria saída na casta armadura:

Oferta e magia. E morre sabendo que a vida existia.

Rio, 1964.

O texto é melhor acabado do que o primeiro, as rimas são mais trabalhadas, as imagens são mais bem construídas. Talvez o fato do poeta utilizar uma forma que remete ao soneto, ainda que não tenha a estrutura métrica de um soneto clássico, ajude nesse melhor acabamento.O uso de uma forma fechada, reforça a figura que o poema retrata, a ostra.

Há no texto uma predominância de versos em redondilha menor, sendo que todos os versos do poema têm acento na segunda sílaba. A regularidade existe tanto no rítmo silábico quanto no ritmo acentual. Essa regularidade parece estranha dentro de um soneto que não é soneto, um soneto que parece ter sido escrito até a cesura. Apesar disso, consegue trazer a mesma força da forma soneto que nos faz pausar a leitura ao fim de cada verso. Isso faz com que as figuras como "jaula", "cofre", "armadura", todas figuras de espaço e todas referentes a um fechamento, sejam realçadas. Dessa vez, parece-nos, matendo a leitura que fizemos no primeiro poema, que a figura que se quer retratar é a do própria escrita e a dificuldade de não se deixar consumir por esse instrumento poderoso. Fica, ao fim do texto, a ideia de que a vida está fora desse espaço fechado que é a escrita.

Cabe lembrar que Cacaso já disse que a experiência do livro foi traumática, que ele credita aos problemas de circulação do livro. Não nos parece forçado dizer que algo desse 
trauma vem da própria experiência de escrita já que, ainda segundo depoimentos do escritor, ele passou os próximos setes anos sem fazer poemas.

O livro apresenta uma preocupação com a escrita, mas ainda longe da sofisticação presente nos ensaios e poemas dos anos 70. Longe também do tipo de reflexão que já se encontra no horizonte da arte no final dos anos 60. A percepção de que há, no período, um parodoxo que envolve as condições de produção e as condições de circulação e recepção, ou, para citar Roberto Schwarz no ensaio-referência "Cultura e política, 1964-69", "um movimento cultural "que veio amadurecer agora, em plena ditadura, quando as sua condições sociais já não existem", é o elemento para o qual queremos chamar a atenção. A tentativa de Schwarz em discutir o parodoxo, com todos os erros, reconhecidos pelo próprio crítico, e acertos, é sintomática das discussões que ocorriam no período, como o embate entre Arena e Oficina, entre poesia práxis, concreta e neo-concreta, o cinema novo e seus críticos (o próprio Schwarz entre eles), todos esses debates têm como pano de fundo a função da arte e sua relação com a sociedade. O período era propício a isso, não apenas pelas óbvias questões políticas, que, pelas razões apontadas no ensaio de Schwarz, podem não ser as mais importantes, mas pelo campo literário que se consolida cada vez mais, pela chegada, através de Antonio Candido e seus orientandos, da literatura contemporânea na academia.

A questão também é levantada por Heloísa Buarque de Hollanda no livro Impressões de Viagem. O uso desse livro nos parece importante, pois colhe alguns depoimentos e traz citações que mostram como os próprios produtores de cultura, e não apenas os escritores, absorviam o probleam. Para o escritor de um lado se colocava o "formalismo exagerado", na figura da vanguarda concreta, mas não apenas, de outro a opção populista, encarnada pelo coleção Violão de Rua, do CPC (Centro popular de cultura) da UNE. Em depoimento à autora, Armando Freitas Filho coloca o seguinte ponto:

“ Naquele tempo o pessoal que fazia o Violão de Rua era um pessoal muito mais velho, Moacir Félix, Geir Campos, etc. e o fato é que eles não davam muita bola pra gente. Achavam que a gente estava errada em termos de linguagem, achavam que a gente tinha que fazer como o Ferreira Gullar fez em João Boa Morte, partindo de um formalismo extremo para uma poesia que eu não podia fazer. (...)” (Hollanda, 1980, p.49)

A opção por um caminho que não seja a vanguarda ou a política ganha importância, pois a produção artística dita engajada não chega ao "povo" e acaba por ser consumida "por um público já 'convertido' de intelectuais e estudantes de classe média”. O alcance das 
vanguardas também é limitado. Contudo, muito provavelmente por essa distância já consolidada, o lugar do intelectual ao lado do povo vai sendo questionado; basta lembrar do show Opinião e a voz que fala com Nara. ${ }^{26}$.

A relação entre fala e escrita, entre construção e expressão, entre arte e vida, todas faces de um mesmo e longo problema da literatura brasileira, pode ser encontrada nos poemas lidos acima, embora sem o devido grau de problematização que virá apenas mais tarde. O livro "Palavra Cerzida" é sui generis na produção de Cacaso. Antonio Carlos de Brito tinha apenas 23 anos ao publicá-lo, era um garoto ainda maturando sua escrita. O livro de fato apresenta problemas e distancia-se do restante da produção do escritor. Sobretudo porque essas relações todas aparecem a partir de problemas do livro e não por serem problematizadas no poema. Apenas queremos apresentar uma chave de leitura que ajude a entender a questão de Cacaso e sua obsessão na busca pela liberdade das formas.

O livro de Cacaso, assim como Sol dos Cegos, livro de 1968 de Chico Alvim, parecem ser sintomáticos de um problema grave que a literatura enfrentou na década de 60 do século passado; a redução das opçoes artísticas ao CPC ou às vanguardas, novamente o embate entre expressão e construção, fala e escrita, vida e arte, ignorava o fato de que já havia o neoconcretismo, movimento que, se não resolveu os problemas literários, apontou caminhos interessantes. Além disso, como é possível perceber nos textos de Heloísa Buarque e Roberto Schwarz, outras artes já tinham levantado a bola: era preciso pensar em novas formas de recepção e circulação.

Veremos que, a partir de 1974, com o livro Grupo Escolar, há uma virada na escrita de Cacaso. Essa virada pode ser explicada não só pelas preferências pessoais do escritor, mas pelo contexto histórico e pelo papel perdido pela literatura na década de 70 .

\subsection{A subjetividade é um problema coletivo}

O livro de 1974, Grupo Escolar, faz parte do coleção Frenesi. A coleção é vista como uma espécia de divisor de águas na produção literária dos anos 70. Uma observação de Armando Freitas Filho retrata essa posição:

$$
\begin{array}{ll}
\text { "A coleção Frenesi, portanto, cristaliza a } \\
\text { mudança de eixo antes apontada }
\end{array}
$$

${ }^{26}$ A referência também aparece no livro Impressões de Viagem, na página 34. 
(Drummond/Cabral) para Oswald/Bandeira; $e$ pelo seu apuro gráfico apresenta, revela $e$ desperta para um maior número de pessoas a produção ainda muito esparsa e não sistematizada dos 'poetas marginais'. Isso se dá, também, pela razão de que os cinco autores que compõem Frenesi possuem uma bagagem já reconhecida pela crítica de melhor nível." (Filho, 2004, p.189).

Aquilo a que o poeta Armando Freitas Filho chama atenção é a materialização de uma mudança que, como colocamos no capítulo 2, começa em 1972 com livro $O$ preço da passagem, de Chacal, e o livro, também de 1972, Me segura que eu vou dar um troço. Discutimos alguns pontos da relação da poesia de Cacaso com a poesia de Oswald, tomado como grande referência para os escritores da geração de 70 , no primeiro capítulo, e vimos como o primeiro livro de Cacaso traz um diálogo intenso como João Cabral. Neste livro, é interessante perceber que é a partir desse livro que nosso poeta começa a exercer o papel pelo qual será mais reconhecido: o de aglutinador. Como vimos, esse papel de multiacadêmico, professor, ensaísta, poeta, letrista culminava, em algumas figura centrais, no papel de agitador cultural, como eram não apenas Cacaso, mas Waly, Chacal e Bernardo Vilhena. Entre eles muitos fizeram parcerias com artistas dos mais diversos, dirigiram cantores, tornaram-se roteiristas da Globo. Nossa leitura é que essa busca por diferentes espaços discursivos, era uma maneira de dar vazão a uma voz que não tinha espaço. Contudo, fica a tensão já apontada: conquistada a voz, aquilo que se diz é quase incomunicável.

No caso de Cacaso, cacofonia irresistível, o uso de ditados populares, uma linguagem mais próxima do cotidiano, somada às referências à tradição literária brasileira, misturando características do primeiro livro com algumas características do livro Beijo na boca, de 1975, são a maneira de construir um espaço no discurso. Um exemplo é o poema "As aparências revelam":

\section{AS APARÊNCIAS REVELAM}

Afirma uma Firma que o Brasil

confirma: "Vamos substituir o

Café pelo Aço."

Vai ser duríssimo descondicionar

o paladar. 
Não há na violência

que a linguagem imita

algo da violência

propriamente dita?

A primeira diferença que vemos em relação ao primeiro livro é o uso com maior frequiência de versos com métrica variada, além de uma linguagem ainda mais próxima do coloquial. Aqui vemos uma característica marcante da poesia marginal: o uso de enunciados diversos, os enunciados que Foucault chama de anônimos. Em relação ao livro de 1975 o uso desse procedimento ainda é alardeado pelo uso das aspas.

Cacaso mostra que aquele é um enunciado estranho ao texto, que teve de ser poetizado. Ainda não são enunciados ou vozes incorporados plenamente ao texto poético, embora ajudem a compor a estrutura do poema. Outro procedimento que orienta a percepção do leitor é o uso de fotografias, presentes na edição original de 1974 e retiradas na edição das poesias completas de 2002. O poema em questão aparece entre duas fotos, uma de uma pichação em um muro com os dizeres "CCC- Viva o Brasil do Brasil União dos" sendo que o restante não está na foto, um provável referência ao Comando de Caça aos Comunistas. A outra imagem mostra uma placa com os dizeres "Justiça Eleitoral- Privativo dos senhores desembargadores e juízes". Embaixo da placa há uma pilha de lixo e entulho. Colocadas antes e depois de um poema que discute a situação brasileira, as imagens reforçam uma determinada leitura, afastando-se da possibilidade de trabalhar os enunciados deslocados de forma a tensioná-los.

$\mathrm{Na}$ primeira estrofe as rimas internas e os repetidos acentos na segunda sílaba dão uma regularida ao verso. É interessante observar como o enunciado "alienígena" quebra a regularida da rima, sem quebrar a regularidade do ritmo. Curiosa a discordância entre a forma que o papel assume no papel e a métrica. Se dividirmos as duas frases da primeira estrofe, "afirma uma firma que o Brasil confirma" e "Vamos substituir o café pelo aço", teremos dois períodos com onze sílabas. Os três versos escondem essa similaridade rítmica, que é perceptível na leitura do poema, e desmentem o título, "as aparências revelam", já que a aparência do poema, mais engana do que revela. O título, aliás, não tem a função de título que algumas vezes exerce nos poemas de Cacaso, ele é de fato um título, mas que cria uma contradição performativa; faz-se a promessa de que as aparências revelaram, quando na verdade elas escondem. 
A segunda estrofe é marcada como um adendo à estrofe anterior. A voz é retomada, o espaço no discurso recuperado. Ela também apresenta o primeiro verso com onze sílabas, mas o segundo tem apenas três. A interpretação literal do enunciado, desmetaforizada, traz humor ao poema, ao mesmo tempo em que revela uma dificulade de simbolização. Essa dificuldade, como apontamos, vem do fato de que a repressão da ditadura não é simbólica, ela se dá diretamente nos corpos. O humor reforça uma distância, títpica do que se chamou de modernização conservadora, entre o que se produz e para quem se produz (qualquer coincidência com o pré-sal...).

A terceira estrofe do poema reforça uma leitura mais tradicional, não só pela forma do poema, uma quadra com três versos de seis sílaba e uma redondilha menor com esquema de rimas $\mathrm{ABAB}$, mas pelo engajamento direto, pouco usual nos textos de Cacaso, e uma espécie de movimento que lembra muito os concretistas: um metapoema dentro do poema. Ainda que a preocupação com o fazer seja algo recorrente na produção de nosso poeta, esse tipo de procedimento que busca mimetizar ou mesmo explicar o movimento crítico do texto, não o é. É uma espécie de enxerto. Vemos que na segunda estrofe o que existe é uma espécie de comentário ao que está sendo realizado na primeira estrofe. Como já apontamos, ao movimento já havia sido dado o devido destaque pelas aspas, reforçado pela leitura de a violência que a linguagem imita, no caso o lema criado por Cacaso, que funciona ${ }^{27}$ como um "slogan" político, bem ao modo do que ainda ouvimos das bocas de nossos políticos, e que como todo pronunciamento vazio é pleno de violência. Em períodos de pleno emprego e de crença cega no progresso, o uso de motes, lemas e "slogans" deveria ser comum; parece-nos que há aí um duplo movimento: a segunda e a terceira estrofes parecem esvaziar a possibilidade de força crítica da primeira estrofe ao questionar o fato de aquela frase com ares políticos, ao contrário de crítica não é outra instância de violência, outra leitura, compatível com a primeira, é a que enxerga no discurso político, e na própria poesia, a mesma violência praticada pelos atos políticos do período. A dupla leitura, conflituosa, parece reforçar o caminho nada fácil escolhido pelo poeta: evitar que as afirmações se tornem derradeiras e colocar em suspensão as próprias afirmações.

A nós essa instabilidade parece ser o modo que Cacaso encontra de lidar com as certezas apresentadas pelas instituições oficiais nos anos 70. A afirmação derradeira, não

\footnotetext{
${ }^{27}$ Não encontramos nenhum "slogan" que remetesse àquele presente no texto de Cacaso, isso não significa que ele não possa ter sido um "slogan" de fato, ou mesmo uma frase pronunciada por algum ministro em uma entrevista.
} 
importa de que lado ela venha, se de esquerda ou de direita, sempre será autoritária, sobretudo em período ditatoriais, em que a liberdade de expressão é tolhida, como o fizeram as patrulhas ideológicas de esquerda, que em muitos momentos assumiam uma perigosa postura de intolerância.

Outro ponto importante na mudança de postura perante a escrita é o espaço destinado a participação do leitor. Cacaso nunca foi um marginal como foi Chacal, por exemplo. Editava seus livros de maneira independente, mas não saia distribuindo os livros de mão em mão. Como vimos, uma das questões do primeiro livro era a dificuldade com a escrita, e a oralidade que pulsava em alguns textos. Vimos também que a literatura, diferente de outras artes, ainda não havia encontrado a melhor maneira de se relacionar com seu público. Se Nara se aproximava do morro, Hélio Oiticica e Ligia Clark chamavam atenção para a relação entre arte e o corpo, a literatura continuava no debate entre expressão e construção.

Cacaso, em nossa opinião, é um dos primeiros a se enveredar por esse debate. Sem falar em superação, em estará aquém ou além, os textos do poeta cacasiano, não se inibem em transitar entre essas duas instâncias. Contudo, isso só aparecerá com toda a força no livro Beijo na Boca

\subsection{Quando a expressão é construída, quando a construção é expressa}

É em um livro de 1975, Beijo na Boca, que a escrita de Cacaso alcança a maturidade. A questão da rarefação da escrita aparece nesse livro, por paradoxal que pareça já que essa é uma obra temática, com poemas bem amarrados, enfim, características que levariam para o fortalecimento da escrita através de sua materialidade.

O paradoxo tem início com o poema de abertura:

\section{E COM VOCÊS A MODERNIDADE}

Meu verso é profundamente romântico.

Choram cavaquinhos luares se derramam e vai por aí a longa sombra de rumores e ciganos.

Ai que saudade que tenho de meus negros verdes anos! 
Em um posfácio para o livro, Clara Alvim faz uma observação bastante interessante sobre a poesia de Cacaso:

(...) na maioria dos poemas de Beijo na Boca, não há afirmação que se fixe como derradeira: dos títulos ao último verso, instaura-se um movimento de contínuo desmentir-se, e parece que a grande luta se trava entre o fazer e o não fazer poema, entre o destruir e o resistir, a destruição da sinceridade ou da seriedade - de conteúdo e de expressão.A autoria e o poema mesmo se fazem e se escondem no atiçar a luta não só de estilos, mas de paródias contra paródias.(Brito, 2000, p.59)

Essa tensão do livro vai sendo construida com as mais diversas situações enunciativas, um deslocamento que vai ocorrendo ao longo de todo o livro. A começar pela capa ${ }^{28}$, deslocando a imagem de capa do livro Cadernos de poesia do aluno Oswald de Andrade, utilizando um esquema de cores e um desenho bastante semelhante:

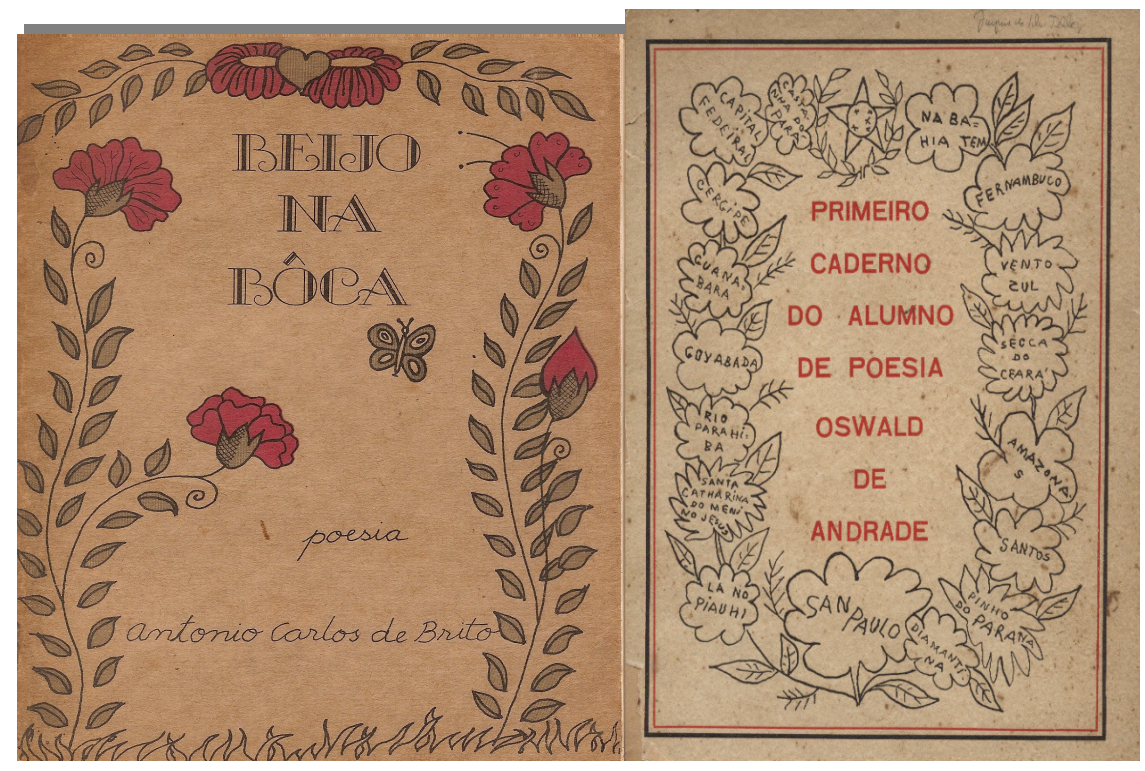

A presença de um modernista já antes mesmo de abrirmos o livro, a epígrafe de Mário de Andrade, "Sou um tupi tangendo um alaúde", famosa pela tensão que expressa entre a

\footnotetext{
${ }^{28}$ A referência ao livro de Oswald Andrade presente na capa de Beijo na boca foi uma observação do professor Marcos Moraes, ao qual agradecemos pelo comentário.
} 
cultura brasileira e a cultura européia, ajuda a situar o leitor e explode neste primeiro poema que anuncia todo o livro como uma paradoxal modernidade e uma tensa relação com o modernismo. O trato com o modernismo aparece sempre nessa tensão, que procuramos trazer ao texto, entre as semelhanças e as diferenças. Esse modernismo que aparece na capa e na epígrafe já não é mais possível. Ele foi institucionalizado e é assim, institucionalizado, que se oferece aos poetas dos anos 70. Por isso, quando Cacaso volta aos modernistas não é na tentativa de reproduzi-los, mas de criar atrito entre as enunciações e os enunciados de modernistas e de marginais, senda uma da razões que leva, como veremos, à uma situação de enunciação impossível, e daí, à escrita rarefeita.

Essa impossibilidade continua na contradição performativa que aparece no título do livro, anunciando o beijo na boca, ato concreto que simboliza o amor, em uma obra na qual o encontro entre dois amantes nunca ocorre, pelo contrário, há uma sucessão de desencontros. A nossa leitura: Cacaso assume em um texto as contradições todas do período. Daí a impossibilidade de cumprir as promessas e ao mesmo tempo nunca deixar de anunciá-las, fazendo com que ocorra a contradição performativa e os constantes deslocamentos de enunciação, deixando-nos sem um chão firme para construir sentidos.

Nesse deslocar de enunciados e enunciações, a poesia repousa sobre a tensão. No poema acima, há uma série de ditos e desditos, a iniciar pelo título que performativamente anuncia o que está por vir, colocando para o leitor a tarefa de descobrir do que se trata aquele conjunto de poemas: onde está a ironia? No poema que se anuncia moderno ou no verso que se anuncia romântico? É possível um poema (ou todo um livro) moderno, com versos românticos? Onde fica a escrita nesse jogo de esconde-esconde, que poderia ser também um jogo de "mostra-mostra"?

Retomando o título, a frase "E com vocês" é usada freqüentemente para apresentar espetáculos como shows musicais, performances e até mesmo apresentações de circo, carregando uma forte marca da língua falada. É um típico proferimento performativo ${ }^{29}$, ou seja, um enunciado que não apenas diz, mas faz algo. A anunciação é simultânea ao ato de anunciar. Contudo, no verso que inicia o poema, a afirmação do título é desmentida e a modernidade tão esperada se acaba em um verso romântico decassílabo ${ }^{30}$. É o que caracteriza

\footnotetext{
${ }^{29}$ Quando utilizamos a idéia de performativo, estamos nos referindo as idéias de J.L. Austin expostas no livro How to do things with words, mas também retomamos Paulo Ottoni no livro Visão performativa da linguagem

${ }^{30}$ Chamamos o verso de decassílabo apesar de não apresentar nenhuma das duas acentuações típicas de versos com esse tipo de métrico (o heróico e o sáfico), sendo acentuado na terceira e na sétima sílaba.
} 
uma contradição performativa. $\mathrm{O}$ ato, porém, pode ou não ser cumprido. No caso do poema, a modernidade que se anuncia é posta em tensão com um verso que se anuncia como romântico. Por isso a contradição performativa.

O verso seguinte parece retirado de um samba-canção e continua no terceiro verso com imagens bastante interessantes: a longa sombra, que poderia remeter a algo negativo, é uma sombra de rumores e ciganos, ou seja, é passageira, não é permanente. Vemos que há diferentes situações enunciativas no poema.

No título, que pode exercer a funçao de primeiro verso, que anuncia a modernidade, temos uma situação enunciativa típica do espetáculo, da indústria cultural. Esse diálogo com outras formas de arte, inclusive com aquelas mais comumente indentificadas com o entretenimento, aparecem com frequiência ao longo do livro. Um exemplo é o poema "Happy End", que mostra, no título, uma mudança no eixo de referências da poesia

\section{Happy End}

o meu amor e eu

nascemos um para o outro

agora só falta quem nos apresente

O desencontro amoroso é marca de poemas ao longo de todo o livro, curiosamente apenas os dois primeiros poemas do livro não tratam do amor como tema, ao menos não diretamente. O título faz referência ao final feliz, típico de filmes, novelas e romances água com açúcar, todos produtos típicos da indústria cultural. Aqui anuncia-se a tão buscada alma gêmea, para a seguir dizer que eles ainda não se encontraram. A ironia amarga dos versos acaba por, mais uma vez, desmentir o título. O final feliz não ocorre. Há uma mudança também na referência cultural, já que o título em inglês mostra uma virada que sai da cultura francófona e passa pela cultura anglófona, com a conseqüente abertura para um diálogo com a indústria cultural. Há, por fim, em comum com o primeiro poema, uma euforia do título que não se consuma.

Voltando ao primeiro poema do livro, ao contrário do que ocorre em "Happy end", a modernidade anunciada pelo título é colocada em tensão já no segundo verso, não precisamos espera até o final para vê-lo desmentido. Ao dizer "meu verso é profundamente romântico", o poeta traz uma reflexão sobre o fazer poético, pois não apenas o verso é romântico, mas sua métrica também, um verso de dez sílabas, fazendo referência ao decassílabo sem assumir 
suas acentuações. É uma forma de desmentir o que se afirma; o verso é profundamente romântico, mas não sua estrutura. As aparências, nesse caso, de fato revelam. Além disso, instaura-se não apenas a tensão entre romantismo e modernidade, mas uma profunda contradição, mais uma entre tantas tão comuns na ditadura, entre euforia e melancolia. A mesma euforia do pleno emprego, a mesma melancolia da voz silenciada. Essa euforia melancólica ou melancolia eufórica, uma quase esquizofrenia, ressurge em outros poemas do livro como neste que segue:

\section{Contando vantagem}

Muitas mulheres na minha vida.

Eu é que sei o quanto dói.

A suposta vantagem de possuir ou ter possuído diversas mulheres torna-se desvantagem quando esse acúmulo de saudades se transforma em dor. Soma-se a ironia quanto a postura de machão, homem conquistador, mas que secretamente sofre com a instabilidade trazida por tantas conquistas. Ao amor que não traz alegria, o amor do desencontro é algo que aparece como temática, embora de forma mais simplificada, sem a força crítica que o amor em Cacaso adquire, do samba-canção.

O samba e a música popular como um todo são referências recorrentes no universo cacasiano. Voltando, mais uma vez, ao primeiro poema, os versos dois e três, "choram cavaquinhos luares se derramam e vai/ por aí a longa sombra de rumores e ciganos.", parecem fazer referência a um samba-canção, além de trazer uma atmosfera romântica ao texto, o que reforça o primeiro verso. No entanto, a indefinição que a expressão "por aî" traz ao texto uma indefinição quanto ao futuro. "Rumores" e "ciganos" também trazem esse caráter, já que ambos possuem como característica a mobilidade. Ciganos são povos nômades, sem terra e rumores são os boatos ainda por se confirmar, aquilo que ainda não tomou forma. A longa sombra, portanto, que traria uma imagem negativa ao texto, parece não ter tempo para acabar, também não tem destino certo. É acompanhada por cavaquinhos que choram e luares que se derramam, o que dá ao texto uma cara de samba-canção. Essa leitura da aproximação com a música popular pode ser feita, pois aparece ao longo de todo livro. $\mathrm{O}$ poema a seguir é um bom exemplo:

\section{SINISTROS RESÍDUOS DE UM SAMBA}


não chore meu amor não chore

que amanhã não será outro dia

A referência ao mundo da canção é anunciada no título, informando o leitor com qual situação enunciativa o poeta está trabalhando. Algo semelhante é realizado por Manuel Bandeira em poemas como o já citado "Poema tirado de uma notícia de jornal" 31 . Podemos deduzir, pelos versos utilizados que se trata das canções "Olê, Olá" e "Apesar de você" de Chico Buarque ${ }^{32}$. Adélia Bezerra de Meneses $^{33}$ faz rápida análise da letra da primeira canção. Segundo ela o motivo principal seria "afastar a tristeza através da força encantatória da música ". Apesar de haver "a proposta da supressão da História, pela supressão do tempo" para "colocar o sofrimento da vida presente entre parênteses (...) o sentimento de efemeridade vence o poema, e o quotidiano se reinstaura, com seu cortejo de limites impostos pelo princípio de realidade: o trabalho, a indiferença das pessoas, a luz do dia (que espaventa a inspiração romântica), a tristeza". Na canção "Apesar de você" há também uma aposta, não na força da música, mas no futuro. Dessa vez, prevalece o otimismo.

No deslocamento das enunciações, que acabam por fazer uma paródia das canções de Chico, Cacaso desfaz as expectativas tanto da possibilidade de música como algo libertador, quanto da expectativa positiva em relação ao futuro. Tal inversão tem inicio já no título: os

\footnotetext{
31 Os procedimentos de deslocamento de enunciação são comuns nos poetas modernistas, mas Manuel Bandeira, ao trabalhar diversos elementos da fala, tensionando-a em relação a escrita, além de trazer elementos cotidianos para a poesia, faz um uso bastante rico desse procedimento.
}

32 A letra da música é a que segue: "Não chore ainda não/Que eu tenho um violão/E nós vamos cantar/Felicidade aqui/Pode passar e ouvir/E se ela for de samba/Há de querer ficar//Seu padre, toca o sino/Que é pra todo mundo saber/Que a noite é criança/Que o samba é menino/Que a dor é tão velha/Que pode morrer/Olê olê olê olá/Tem samba de sobra/Quem sabe sambar/Que entre na roda/Que mostre o gingado/Mas muito cuidado/Não vale chorar//Não chore ainda não/Que eu tenho uma razão/Pra você não chorar/Amiga me perdoa/Se eu insisto à toa/Mas a vida é boa/Para quem cantar//Meu pinho, toca forte/Que é pra todo mundo acordar/Não fale da vida/Nem fale da morte/Tem dó da menina/Não deixa chorar/Olê olê olê olá/Tem samba de sobra/Quem sabe sambar/Que entre na roda/Que mostre o gingado/Mas muito cuidado/Não vale chorar//Não chore ainda não/Que eu tenho a impressão/Que o samba vem aí/E um samba tão imenso/Que eu às vezes penso/Que o próprio tempo/Vai parar pra ouvir//Luar, espere um pouco/Que é pro meu samba poder chegar/Eu sei que o violão/Está fraco, está rouco/Mas a minha voz/Não cansou de chamar/Olê olê olê olá/Tem samba de sobra/Ninguém quer sambar/Não há mais quem cante/Nem há mais lugar/O sol chegou antes/Do samba chegar/Quem passa nem liga/Já vai trabalhar/E você, minha amiga/Já pode chorar"

${ }^{33}$ Meneses, Adélia Bezerra de. Desenho Mágico. São Paulo: Editora Hucitec,1982. p.56. 
resíduos sinistros já demovem o leitor da idéia de encontrar no texto algo positivo, não só por se tratar de resíduos de um samba, ou seja, são os restos inúteis de uma canção, como são sinistros. A palavra "sinistro", segundo o dicionário Houaiss, pode significar como adjetivo: "1 que usa preferencialmente a mão esquerda (diz-se de pessoa); esquerdo, canhoto; 2 que pressagia acontecimentos infaustos; agourento, funesto; 3 que é pernicioso; mau; 4 que se deve temer; assustador, temível; 5 que causa o mal; pernicioso, perigoso; 6 trágico, calamitoso". Excetuado o primeiro sentido, que não nos interessa aqui, todos os outros trazem um caráter extremamente negativo. A segunda acepção é particularmente interessante para a comparação entre os três textos. Se nas canções de Chico predomina a esperança, a expectativa positiva, mesmo quando não realizada como no caso de "Olê, Olá", em Cacaso de cara a esperança é derrubada. Ele toma a parte otimista de "Olê, Olá" e junta-a com uma parte de "Apesar de você" destituída de todo seu valor positivo. Assim, apostando que o seu interlocutor reconhecerá os enunciados, já que ele deu a "dica" de onde foram retirados, o poeta subverte o sentido de ambos, criando um novo enunciado despido de toda positividade dos textos de Chico, mas que necessita do otimismo para criar um atrito. $\mathrm{O}$ movimento de deslocamento do sentido faz com que a negação ganhe ares de desolação e conformidade ao mesmo tempo: o choro, diferentemente da maneira como é enunciado na canção de Chico, onde ganha força expressiva em uma situação sem esperanças, não é necessário, pois a situação já está dada e não virá outro dia para reacender as esperanças.

Esse procedimento de subverter as expectativas do leitor é recorrente em Cacaso e aparece com força máxima no livro Beijo na Boca. O texto perde sua estabilidade já que o novo sentido depende do sentido original para ser compreendido em toda sua extensão. A enunciação se cria no espaço entre o novo enunciado e o enunciado antigo. Sem o repouso de sentido, não há afirmação definitiva, não há percepção que se cristalize. O movimento de ir e vir pode se originar de diversas outras situações enunciativas, mas carrega uma relação muito interessante entre fala e escrita. È importante ressaltar que trabalhar com a fala não é necessariamente fazer transcrições de diálogos ou adaptar a escrita à fonética da língua falada. Remeter a situações de enunciação onde há predominância da fala é um outro modo de trabalhar a relação entre fala e escrita. Do mesmo modo, trabalhar a escrita não é apenas radicalizá-la como, por exemplo, fez Mallarmé. Apoiar-se na tradição literária brasileira é fazer referência a uma situação enunciativa tipicamente escrita. $O$ gênero poético, sobretudo no século XX, consolidou-se como espaço da escrita. Para que não fiquemos em uma explanação abstrata, tomemos o poema "Sinistros resíduos de um samba". A referência a 
situação enunciativa da canção, espaço onde há predominância das estruturas da fala, é colocada em contraste com o próprio espaço da poesia.

A referência ao mundo da escrita aparece, voltando pela última vez ao primeiro poema, no diálogo com a tradição. A referência é também ao romantismo: uma paródia ${ }^{34} \mathrm{de}$ um verso de Casimiro de Abreu. Aqui cabe uma pausa para traçar uma diferença entre Cacaso e os modernistas. Se a paródia no poetas de 22, sobretudo Oswald, tinha um caráter desmistificador e até mesmo destruidor, no poeta dos anos 70 a paródia perde um pouco de sua força humorística e se faz crítica na incorporação das questões formais do poema "Meus oito anos" de Casimiro de Abreu, para criar uma nova situação enunciativa. O texto de Abreu é composto de versos em redondilha maior, o último verso do poema de Cacaso tem quinze sílabas tônicas, mas pode ser divido em dois versos de sete sílabas (Ai que saudades que tenho/ de meus negros verdes anos) mantendo diálogo com a estrutura original, mas atualizando-a.

Como dissemos, o jogo que se faz é entre fala e escrita, ou melhor, entre situações enunciativas da fala e situações enunciativas da escrita. Via de regra a escrita aparece na forma das referências literárias, do diálogo com a tradição e, algumas vezes, o próprio poema é a referência escrita. Voltando ao primeiro poema, "E com vocês a modernidade", a presença da escrita se faz por meio do diálogo com a tradição romântico da literatura, não apenas através da paráfrase, mas também pelo diálogo com o imaginário comum sobre a temática romântica. As situações da língua falada aparecem como referência ao cotidiano ou a situações ocorridas no período. Esse contraste pode ser quase todo exemplificado no último verso. Além da referência estrutural já comentada, temos também a temática da infância carregada de saudosismo, tema caro aos românticos, retomado por Bandeira. No poema de Cacaso, o tempo passado não é necessariamente a infância, mas são os "negros verdes anos". Os verdes parecem ser um tempo onde ainda havia esperança. O adjetivo "negro" refere-se, nesse caso, a algo ruim ou a algum tipo de desvio, como na expressão "ovelha negra", o que, nos anos 70, não seria necessariamente negativo. O termo "negros verdes anos" pode, portanto, tanto significar algo negativo, uma infância ou um tempo de esperança marcado por algum tipo de negatividade, como um tempo cheio de esperança, quando havia a

\footnotetext{
${ }^{34}$ A discussão sobre as diferenças entre paródia, paráfrase e ironia é bastante extensa. Remete a Bakhtin e aos Formalistas Russos, passa pelos estudos da ironia bastante comuns nos críticos pós-modernos como Linda Hutcheon. Para simplificar, já que nosso objetivo toma outro foco, chamaremos de paráfrase o uso que constrói um novo sentido para um enunciado, seguindo um pouco o que Affonso Romano Sant'Anna propõe no livrinho Paródia, Paráfrase \& Cia.
} 
possibilidade de desvio, de afastamento. Somados ao restante do poema e aos anos de ditadura, a segunda leitura se sustenta. Até mesmo porque, o termo "saudade" traz uma idéia positiva sobre um período que não existe mais. Essa infância que se perdeu mistura-se com a juventude que está sendo perdida e com a maturidade se perderá, daís os negros verdes anos durante a ditadura $\mathrm{O}$ futuro, o presente e o passado se misturam de forma contraditória e complexa. Assim, o saudosismo não é acompanhado, como nos românticos, de um desejo de fugir da realidade, mas de enfrentá-la. É o exílio e a saudade, na verdade uma espécie de auto-exílio, uma impossibilidade de se saber onde se está; estamos por aí, entre romantismo e modernidade, entre euforia e melancolia, entre fala e escrita, entre canção e literatura. É a contradição formadora dos anos 70 que aparece mais uma vez: a conquista da autonomia do campo literário e de uma série de outras liberdades ocorre em um período de repressão, no qual não deveria haver espaços para conquistas.

Como conseqüência, temos o que viemos chamando de rarefação da escrita. Isso não significa que o texto perca força em sua materialidade ou que haja uma predominância da fala sobre a escrita nos poemas de Cacaso. Há um processo que faz do poema uma espécie de instância privilegiada das contradições diversas do período que apontamos até aqui. Utilizados como lados de uma mesma moeda, e não como armas em um confronto, expressão e construção, fala e escrita, liberdade e repressão, arte e vida tornam-se ferramentas críticas importantes, marca de grandes escritores, em especial grandes poetas, em diferentes épocas. Cacaso dá outra função a esse trânsito, mostrando os limites da criação. Pondo em xeque concepções sobre a poesia, ele constrói um espaço discursivo no qual há espaço para a voz, mas ela prefere se calar ou colocar afirmações que nunca são derradeiras, promessas que não se cumprem, situações enunciativas que são familiares ao leitor, mas que criam um novo sentido.

A rarefação da escrita é a junção dessas possibilidades, algo que ocorre nos bons poemas de Cacaso. É essa constante ressignificação, por meio das ferramentas das mais variadas, que faz com que, paradoxalmente, como não poderia deixar de ser, o discurso ganhe força, quando o lastro maior de qualquer discurso, o corpo, já não está sobre os domínios do sujeito. Criam-se espaços discursivos, algo que todos os bons poetas marginais fizeram, mas nunca se deixa preenchê-los por completo. É como se a função-sujeito criada pela poesia marginal fosse um espaço que se deixa sempre vazio, um corpo que não se pode controlar, pois não pertence a ninguém. 


\section{Bibliografia}

\section{De Cacaso:}

BRITO, Antônio Carlos de (Cacaso). Lero-Lero. São Paulo, Cosac \& Naif, 2002. Beijo na boca. São Paulo, 7letras, 2000.

Beijo na boca. Rio de Janeiro, 1975. Edição do autor Não quero prosa. Campinas: Editora da Unicamp, Rio de

Janeiro: Editora da UFRJ, 1997.

\section{Sobre Cacaso e a poesia marginal:}

ALVIM, Clara de Andrade. Esses poetas de hoje. In: Beijo na boca. São Paulo, 7letras, 2000. ARAGÃO, Daniela Pedreira. Figurações poéticas em Cacaso: o letrista e o poeta. Mestrado, UFRJ-CFCH, Rio de Janeiro, 2004.

ARAGÃO, Helena. O poeta que escuta. Inimigo Rumor. Rio de Janeiro, n8, maio, 2000.

AUGUSTO, Eudoro. Na casa de Cacaso. Inimigo Rumor. Rio de Janeiro, n8, maio 2000. BOAVENTURA, Cristiana Tiradentes. A crítica de Ana Cristina Cesar em Escritos no Rio. Mestrado. FFLCH-USP. São Paulo, 2007.

BOSI, Viviana. "As faces da musa em Francisco Alvim". In: Pedrosa, Celia; Camargo, Maria Lucia de Barros, orgs. Poéticas do olhar : e outras leituras de poesia. Rio de Janeiro, 7Letras, 2006.

“Années soixante-dix, la poésie en risque: la veille du trapéziste". In: Rita

Olivieri-Godet; Andrea Hossne. (Org.). La littérature brésilienne contemporaine de 1970 à nos jours. 1 ed. Rennes: Presses Universitaires de Rennes, 2007, v. , p. 161-178.

CABAÑAS, Teresa. Que poesia é essa?! Poesia marginal: a estética desajustada.

Doutorado. IEL-Unicampo. Campinas, 1998.

CANDIDO, Antonio. A literatura brasileira em 1972. Arte em revista. São Paulo, Kairós Editora, ano1,n.1 jan./mar. 1979. 
CAVALCANTE, José Francisco. Cacaso: poeta da canção. Mestrado, USP- FFLCH, São Paulo, 2008.

CÈSAR, Ana Cristina e MORICONI, Ítalo. "O poeta fora da república” in Jornal Opinião, Rio de Janeiro, 25 de março de 1977. pp.19-20

CÉSAR, Ana Cristina. A teus pés. São Paulo, Ática, 1999. 2. ed.

CÉSAR, Ana Cristina. Inéditos e Dispersos. São Paulo, Ática e Instituo Moreira Salles, 1998, 3. ed.

CHACAL. Drops de abril. São Paulo, Brasiliense, 1983.

HOLLANDA, Heloísa Buarque de (org.) 26 poetas hoje. Rio de Janeiro: Aeroplano,2001. Impressões de Viagem: Cpc, vanguarda e desbunde 1960-1970. São Paulo:

Brasiliense, 1980.

. Cultura e participação nos anos 60. São Paulo: Brasiliense, 1990. . O poemão de todos nós. Jornal do Brasil, 12/04/2003

LANDIM, Pedro. Carinho eterno. Inimigo Rumor. Rio de Janeiro, n.8, maio, 2000.

LITRON, Fernanda Felix. Poesia marginal e a antologia "26 poetas hoje": debates da crítica antes e depois de 1976. Mestrado, Unicamp-IEL, Campinas 2007.

MAGALHÃES, Milena. Cacaso não é bem o caso do acaso. Revista de Letras, São Paulo, n. 45,2005

MARTIN, Carlos Frederico Barrére. A véspera do trapezista. Leitura da poesia de Antônio

Carlos de Brito. Mestrado, USP-FFLCH, São Paulo, 2008.

OLIVEIRA, Ana Maria Domingues. Dever de caça: a poesia de Cacaso. Literatura e Sociedade, São Paulo, n.8, 2005

PEREIRA, Carlos A. M. Retrato de Época Rio de Janeiro: Funarte, 1981.

Rebate de Pares (críticos e poetas). Remate de males, Campinas, n.2, 1981.

SIMON, Iumna Maria; DANTAS, Vinicius. "Poesia ruim, sociedade pior”. In: Novos estudos CEBRAP. São Paulo, n. 12, p. 48-61, jun. 1985.

SOARES, Débora Racy. Um frenesi na corda bamba: análise crítica da obra poética GRUPO ESCOLAR (1974) de Antônio Carlos de Brito Mestrado: Unesp-FCLAR, 2003. - “Para viver alguns pequenos amores: notas sobre Beijo na Boca de

Cacaso”. In: Estudos Linguísticos, São Paulo, n 37 v. 3, p. 159-167, set-dez 2008.

SCHWARZ, Roberto. "No país do elefante”. In: MAIS! Jornal Folha de São Paulo (10 março 2002). 
SÜSSEKIND, Flora Literatura e vida literária: polêmicas, diários e retratos Belo Horizonte: UFMG, 2000.

. “Hagiografias" In: Inimigo Rumor, n 20, maio 2008.

ZULAR, Roberto. "O que fazer com o que fazer? : algumas questões sobre o Me segura qu'eu vou dar um troço de Waly Salomão”. In: Literatura e Sociedade São Paulo, n. 8, p. 46-59, 2005

\section{Bibliografia Geral}

ADORNO, T. W. Notas de Literatura I. Tr. Jorge de Almeida. São Paulo: Duas Cidades; Ed.34, 2003.

AGAMBEN, Giorgio. Estado de Exceção: Homo Sacer II. São Paulo: Boitempo, 2007. .Categorie Italiane: Studi di poetica. Veneza: Marsilio, 1996.

ALVIM, Franciso Poesia Reunida Sao Paulo : Duas Cidades, 1988

ANDRADE, Mário de. O Baile das quatro artes. São Paulo: Livraria Martins editora, 1963. Obra imatura. 3.ed. São Paulo: Martins; Belo Horizonte: Itatiaia,

1980.

Aspectos da literatura brasileira. 6.ed. São Paulo: Martins, 1978.

ANDRADE, Oswald. Poesias Reunidas. 3.ed. Rio de Janeiro: Civilização Brasileira, 1972.

ARRIGUCCI Jr, David. Humildade, Paixão e morte: a poesia de Manuel Bandeira. 2. reimp.

São Paulo: Companhia das Letras, 2001.

AUSTIN, J.L. How to do things with words. Oxford: Oxford University Press, 1975.

BOURDIEU, Pierre. A Economia das Trocas Simbólicas. São Paulo, Perspectiva, 2004.

BOURDIEU, Pierre. Les Regles de l'Art: genese e structure du champ litteraire. Paris, Du Seuil, 1992.

CAMPOS, Haroldo de. "Uma poética da radicalidade". In: Poesias reunidas de Oswald de Andrade. Rio de Janeiro, Civilização Brasielira, 1971. p. 9-62.

CANDIDO, Antonio. Literatura e sociedade: estudos de teoria e história literária. 8.ed. São Paulo: T.A. Queiroz, 2000. . Vário escritos. 3.ed. revista e ampliada. São Paulo: Duas Cidades, 1995. Formação da literatura brasileira: momentos decisivos. São Paulo:

Ouro sobre azul, 2005. 
CULLER, J. Philosophy and literature: the fortunes of performative. Poetics Today, volume 21 , number 3 fall 2000.

DANTAS, Vinicius. A poesia de Oswald de Andrade. Novos Estudos. São Paulo, n. 30,julho, 1991

Capítulos Obscuríssimos da crítica de Mário e Oswald. Novos Estudos.

São Paulo, n.57, julho, 2000.

FOUCAULT, M. O que é um autor? Tr. António Fernando Casais e Edmundo Cordeiro 2.ed.

S.L. Passagens, 1992.

GORMAN, D. The use and abuse of speech-act theory in criticism. Poetics today, volume 20, number 1 spring 1999.

HOLANDA, Sérgio Buarque de. O espírito e a letra. São Paulo, Cia das Letras, 1996, 2 v.

KRISTEVA, Julia. Bakhtine, le mot, le dialogue et le roman. Critique, Paris, n.239, 1973.

LAFETÁ, João Luiz. 1930: a crítica e o modernismo. 2.ed. São Paulo: Duas Cidades; Ed.34, 2000 .

MESCHONNIC, Henri. Critique du rythme. Lagrasse: Verdier, 1982.

. La rime et la vie. Lagrasse: Verdier, 1990.

. Politique du rythme. Lagrasse: Verdier, 1995.

MICELI, Sérgio Intelectuais à brasileira. São Paulo: Cia das Letras, 2001

MOURA, Flávio Rosa. Diálogo crítico : disputas no campo literário brasileiro (1984-2004).

Mestrado, USP-FFLCH, São Paulo, 2004.

OTTONI, Paulo. Visão performativa da linguagem. Campinas: Editora da Unicamp, 1998.

SCHWARZ, Roberto. "No país do elefante”. In: MAIS! Jornal Folha de São Paulo (10 março 2002).

. "A carroça, o bonde e poeta modernista". In: Que horas são? São

Paulo, Cia das letras, 1987.

. "O psicologismo em Mário de Andrade. In: A sereia e o desconfiado.

São Paulo: Duas cidades, 1965.

TODOROV, Tzvetan \& DUCROT, Oswald. Dictionnaire encyclopédique des sciences du langage. Paris, Éditions du Seuil, 1984. 